Article

\title{
Survival, Height Growth, and Phytoextraction Potential of Hybrid Poplar and Russian Olive (Elaeagnus Angustifolia L.) Established on Soils Varying in Salinity in North Dakota, USA
}

\author{
Ronald S. Zalesny Jr. ${ }^{1, *}$, Craig M. Stange ${ }^{2}$ and Bruce A. Birr ${ }^{1}$ \\ 1 USDA Forest Service, Northern Research Station, Institute for Applied Ecosystem Studies, 5985 Highway K, \\ Rhinelander, WI 54501, USA \\ 2 USDA Natural Resources Conservation Service, Bismarck Plant Materials Center, 3308 University Drive, \\ Bismarck, ND 58504, USA \\ * Correspondence: ron.zalesny@usda.gov; Tel.: +1-715-362-1132; Fax: +1-715-362-1166
}

Received: 24 May 2019; Accepted: 28 July 2019; Published: 9 August 2019

Abstract: Salt-affected soils in the Northern Great Plains, USA, can impact the long-term survival and growth of trees recommended for agroforestry systems, with Russian olive (Elaeagnus angustifolia L.) being one of few options that survives on these sites. Similarly, hybrid poplars have been used for phytotechnologies on high-salinity soils throughout the world. The objective of this study was to test the survival, height growth, and phytoextraction potential of eight hybrid poplar clones (Populus deltoides Bartr. ex Marsh. $\times$ P. nigra L. 'Robusta', 'DN17', 'DN182', 'DN5'; P. deltoides $\times$ P. maximowiczii A. Henry 'NC14104', 'NC14106'; P. nigra $\times$ P. maximowiczii 'NM2', 'NM6') versus Russian olive grown on soils categorized according to initial salinity levels: low ( 0.1 to $\left.3.9 \mathrm{dS} \mathrm{m}^{-1}\right)$, medium (4.0 to $\left.5.9 \mathrm{dS} \mathrm{m}^{-1}\right)$, and high $\left(6.0\right.$ to $\left.10.0 \mathrm{dS} \mathrm{m}^{-1}\right)$. Seven trees per genotype were grown in each salinity treatment at a spacing of $3 \times 3 \mathrm{~m}$ for four years in Burleigh County, North Dakota. Survival and height were determined following the first four growing seasons, and leaf phytoextraction potential of $\mathrm{Al}, \mathrm{Ca}, \mathrm{Cd}, \mathrm{Fe}, \mathrm{K}, \mathrm{Mg}, \mathrm{Mn}, \mathrm{Na}$, and $\mathrm{Zn}$ was measured for one-year-old trees. Soil salinity decreased over time, reflecting the phytoextraction potential of the trees. Russian olive did not survive as well as expected, having lower overall survival than three of the hybrid poplar clones ('DN17', 'DN5', 'NM6'). At the end of three years when trees were removed per a landowner maintenance agreement, $86 \%, 71 \%$, and $43 \%$ of the Russian olive trees were alive in the low-, medium-, and high-salinity soils, respectively. At this time, 'NM2' was the only hybrid poplar clone with similar survival to Russian olive in the high-salinity soils. Russian olive had greater $\mathrm{Na}, \mathrm{Cd}$, and Fe leaf concentrations than the hybrid poplar clones, but it also had the worst uptake of $\mathrm{Ca}$ and $\mathrm{Mg}$ of all genotypes. For hybrid poplar, the $P$. deltoides $\times$ P. nigra genomic group had the broadest clonal variability among all traits, with 'Robusta' and 'DN182' exhibiting great potential for establishment on high-salinity soils. 'Robusta' and 'DN17' are the same genotype but they came from different nursery sources (i.e., hence their different nomenclature), and they did not differ for height nor leaf phytoextraction. Populus deltoides $\times$ P. maximowiczii clones were not suitable for the soil conditions and silvicultural applications (e.g., tree shelters) of the current study, while P. nigra $\times$ P. maximowiczii clones exhibited the most stable performance across all years and salinity treatments. Both 'NM2' and 'NM6' had superior fourth-year survival and height, as well as average or above average phytoextraction of all elements tested.

Keywords: agroforestry; metal uptake; phytoremediation; phytotechnologies; Populus; salt uptake 


\section{Introduction}

Agroforestry practices such as planting trees and shrubs in agricultural areas are useful for moderating winds, managing snow distribution, and reducing energy demands for snow removal, livestock feed, and heating buildings [1]. However, salt-affected soils such as those in the Northern Great Plains of North Dakota, USA, can prevent or reduce the long-term survival and growth of trees and shrubs recommended for agroforestry systems [2]. Russian olive (Elaeagnus angustifolia L.) is one of the few tree species that is salt tolerant and able to withstand these high-salinity soil conditions such as those in the region [3-5], yet the species is highly invasive and has spread into riparian habitats throughout much of western North America [6]. As a result, landowners are often faced with the choice between dealing with Russian olive and the potential for its invasive biology to impact the environment, or not being able to have viable options for afforestation of their lands.

To address the need for other tree options that can be established on these high-salinity soils, researchers at the US Department of Agriculture (USDA) Northern Research Station and their collaborators have been developing genotypes of hybrid poplars (Populus species and their hybrids) for decades to provide biomass feedstocks for biofuels, bioenergy, and bioproducts [7-9], as well as "green tools" for phytoremediation and associated phytotechnologies $[10,11]$. Two advancements in these regional hybrid poplar development programs have provided the potential for identification of pure species or hybrids that can survive and thrive on these salty soils. First, phyto-recurrent selection was developed as a data-driven methodology for choosing hybrid poplar clones to appropriately match the particular climatic and soil conditions of field sites $[12,13]$. Second, based on the use of phyto-recurrent selection in phytotechnologies related to highly-salinity wastewater irrigation, certain hybrid poplar genotypes have been identified that can tolerate salinities as high as $9 \mathrm{dS} \mathrm{m}^{-1}$ [14-16], which may provide tree options for planting in the Northern Great Plains.

Similar activities by the USDA Agricultural Research Service (USDA ARS) in the southwestern United States have corroborated this potential application for hybrid poplars [11,17]. For example, Bañuelos et al. [18] and Shannon et al. [19] reported broad genetic variation in salt tolerance among eight hybrid poplar genotypes belonging to three genomic groups. Genotype-specific biomass impacts occurred at salinities ranging from 3.3 to $7.6 \mathrm{dS} \mathrm{m}^{-1}$, with each salinity unit decreasing biomass by 10 to $15 \%$. More recently, Bañuelos et al. [20] tested hybrid poplar growth and uptake of boron (B) following irrigation with high salinity and high B waters, and they reported seasonal fluctuations in $B$ and chloride $\left(\mathrm{Cl}^{-}\right)$uptake along with tolerance and lack of biomass impacts of some clones.

Although less salinity research has been conducted for trees than agricultural crops, select studies have classified salt tolerance of poplars. For example, Mirck and Zalesny [21] classified poplars as sensitive to moderately salt tolerant depending on genomic groups and specific genotypes within groups. Regardless of plant type, classifying salinity tolerance depends on salt concentrations, measurement methods, and source of salinity treatments [21]. In particular, for treatment sources, salinity may be: (1) introduced via wastewaters such as landfill leachate, (2) present in groundwaters, or (3) naturally occurring in soils. In addition to those cited above, studies testing salt tolerance of poplars have included soil salinities ranging from 0.1 to $15.5 \mathrm{dS} \mathrm{m}^{-1}$ [22-25], with tolerance thresholds ranging from 2.3 to $5.0 \mathrm{dS} \mathrm{m}^{-1}$ and electrical conductivity values of root zone salinity resulting in $50 \%$ biomass reductions (i.e., $\mathrm{C}_{50}$ values) ranging from 3.3 to $5.8 \mathrm{dS} \mathrm{m}^{-1}$ [26]. Salinity studies of poplars have occurred in short durations under controlled environments [25], and through entire rotations with practical field applications [27], thus resulting in opportunities for combining poplar phytoremediation and agroforestry [28].

Recently, Limmer et al. [29] reported results of using hybrid poplar clone 'HP-308' (Populus charkowiensis Schröder $\times$ P. incrassata Dode) and Russian olive for phytoremediation of benzene, toluene, and chlorobenzene, which is the first field-scale report that we know of combining these genera for phytotechnologies. The objective of the current study was to compare the performance of known saline-tolerant hybrid poplar genotypes compared with Russian olive at a field site in Burleigh County, North Dakota that had soils naturally varying in salinity. Specifically, based on initial salinity 
values, we categorized the soils as low $\left(0.1\right.$ to $\left.3.9 \mathrm{dS} \mathrm{m}^{-1}\right)$, medium $\left(4.0\right.$ to $\left.5.9 \mathrm{dS} \mathrm{m}^{-1}\right)$, and high (6.0 to $10.0 \mathrm{dS} \mathrm{m}^{-1}$ ) salinity treatments and grew eight hybrid poplar genotypes plus a Russian olive accession for four growing seasons. We tested for differences among salinity treatments, genotypes, and their interactions for tree survival, height growth, and phytoextraction potential of salts and metals (i.e., the uptake of salts and metals into leaf tissue in the current study, where greater concentrations equal higher potential). This information is important for researchers, land managers, and landowners when making decisions about species selection for agroforestry systems in the region.

\section{Materials and Methods}

\subsection{Site and Soils Description}

The study site was located in Burleigh County, near Bismarck, North Dakota, USA $\left(46.82707^{\circ} \mathrm{N}\right.$, $-100.59790^{\circ} \mathrm{W}$ ) (Figure 1). The soils were classified as Harriet loam, and soil properties of the study area are shown in Tables 1 and 2. Given heterogeneity in soil salinity across the site, initial salinity levels were mapped 21 days before planting on 20 May 2014 (Figure 2), and then at seven additional dates throughout the study (Table 1). Electrical conductivity (EC) readings were measured with a FieldScout Direct Soil EC Meter at $23 \mathrm{~cm}$ depth (Spectrum Technologies, Inc., Plainfield, Illinois, USA). Salinity values are reported as 1:1 measurements. The initial salinity ranges were categorized into three soil treatments: low $\left(0.1\right.$ to $\left.3.9 \mathrm{dS} \mathrm{m}^{-1}\right)$, medium $\left(4.0\right.$ to $\left.5.9 \mathrm{dS} \mathrm{m}^{-1}\right)$, and high $\left(6.0\right.$ to $\left.10.0 \mathrm{dS} \mathrm{m}^{-1}\right)$. Figure 2 illustrates the locations of these treatments across the site.

On 27 August 2014, six soil samples from each salinity treatment were collected to a depth of $30 \mathrm{~cm}$ (Figure 2) and brought back to the USDA Forest Service, Institute for Applied Ecosystem Studies in Rhinelander, Wisconsin, USA for laboratory analyses of $\mathrm{pH}$, EC, chloride $\left(\mathrm{Cl}^{-}\right)$, and the following elements: aluminum $(\mathrm{Al})$, cadmium $(\mathrm{Cd})$, calcium $(\mathrm{Ca})$, cobalt $(\mathrm{Co})$, chromium $(\mathrm{Cr})$, copper $(\mathrm{Cu})$, iron $(\mathrm{Fe})$, potassium $(\mathrm{K})$, magnesium $(\mathrm{Mg})$, manganese $(\mathrm{Mn})$, sodium $(\mathrm{Na})$, nickel $(\mathrm{Ni})$, lead $(\mathrm{Pb})$, and zinc (Zn) (Table 2).

A Fisher Scientific Accumet XL-50 m (Thermo Fisher Scientific, Carlsbad, California, USA) was used to measure $\mathrm{pH}, \mathrm{EC}$, and $\mathrm{Cl}^{-}$. For $\mathrm{pH}, 4 \mathrm{~g}$ of air-dried, crushed, and sieved soil samples $(\leq 2 \mathrm{~mm}$ particle size) were weighed into 5-dram clear polystyrene vials (Thornton Plastics, Salt Lake City, Utah, USA), and $5 \mathrm{~mL}$ of $0.01 \mathrm{M}$ calcium chloride $\left(\mathrm{CaCl}_{2}\right)$ was added. The vials were capped, placed horizontally on an orbital shaker, and shaken at $80 \mathrm{rpm}$ for $40 \mathrm{~min}$. The vials were then placed in a tray, caps removed, and $\mathrm{pH}$ measured using a Fisherbrand ${ }^{\mathrm{TM}}$ AccuCap ${ }^{\mathrm{TM}}$ capillary junction $\mathrm{pH}$ electrode (Thermo Fisher Scientific, Carlsbad, California, USA). The meter was calibrated with buffer standards prepared from Fisher Buffer Salt of pH 4.01 and 7.41 (Thermo Fisher Scientific, Carlsbad, California, USA).

For EC and $\mathrm{Cl}^{-}, 4 \mathrm{~g}$ of dried, crushed, and sieved soil samples ( $\leq 2 \mathrm{~mm}$ particle size) were weighed into 5-dram clear polystyrene vials (Thornton Plastics, Salt Lake City, Utah, USA), and $5 \mathrm{~mL}$ of water purified with a RODI-T2 reverse osmosis plus Type II DI system (Aqua Solutions, Jasper, Georgia, USA) was added $[15,21]$. The vials were handled and shaken in the same manner as for $\mathrm{pH}$. Electrical conductivity was measured using a Fisherbrand ${ }^{\mathrm{TM}}$ Accumet $^{\mathrm{TM}}$ temperature-compensated two-cell conductivity probe using standards prepared from $5000 \mathrm{dS} \mathrm{m}^{-1}$ conductivity standard (Ricca Chemical, Arlington, Texas, USA). After the EC measurements, $0.1 \mathrm{~mL}$ of $5-\mathrm{M}$ sodium nitrate $\left(\mathrm{NaNO}_{3}\right)$ solution was added as an ionic strength adjustor to each vial. The solution was mixed thoroughly, and $\mathrm{Cl}^{-}$ was measured using a Fisherbrand ${ }^{\mathrm{TM}}$ Accumet ${ }^{\mathrm{TM}}$ solid-state half-cell $\mathrm{Cl}^{-}$-specific electrode using standards prepared from $1000 \mathrm{mg} \mathrm{L}^{-1} \mathrm{Cl}^{-}$standard (Ricca Chemical, Arlington, Texas, USA). 

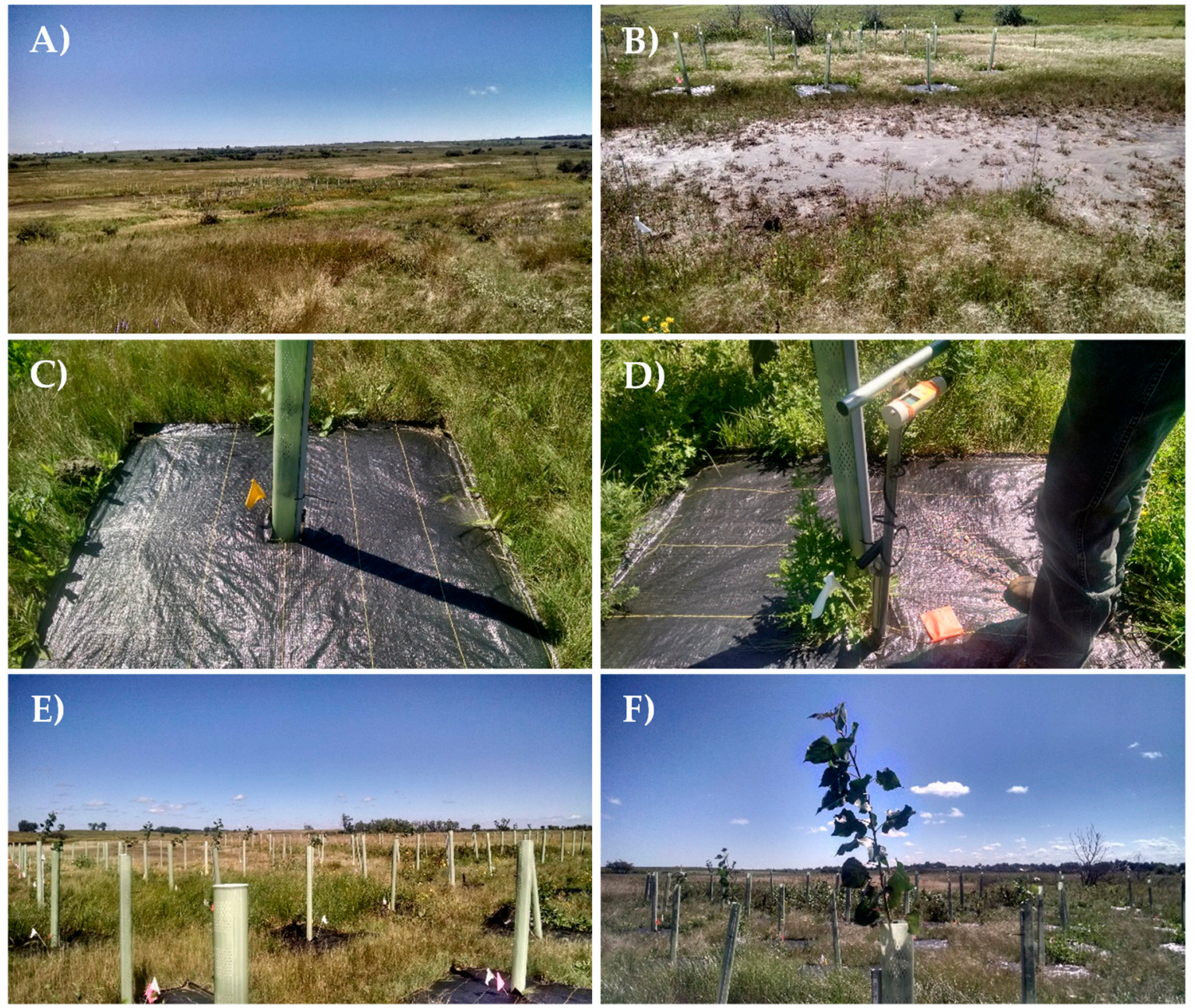

Figure 1. (A) Landscape of the Northern Great Plains in North Dakota, USA, with the study plot and trees planted into tree shelters in the center of the photo. (B) Surface salt crust of the soils at the study plot; note trees planted into tree shelters in the background. (C) Black weed barrier fabric protecting each tree from competition. (D) FieldScout Direct Soil EC (electrical conductivity) Meter with 61-cm T-handle probe used to measure soil salinity levels (Spectrum Technologies, Inc., Plainfield, Illinois, USA). (E) Trees growing at the study plot. (F) Poplar clone 'DN5' (Populus deltoides $\times$ P. nigra) growing out of its $1.5-\mathrm{m}$ tree shelter. All photos were taken by Ron Zalesny (USDA Forest Service) at 77 days after planting.

An Agilent AA240FS fast sequential atomic absorption spectrometer (Agilent Technologies, Santa Clara, California, USA) was used to analyze for soil concentrations of $\mathrm{Al}, \mathrm{Cd}, \mathrm{Ca}, \mathrm{Co}, \mathrm{Cr}, \mathrm{Cu}, \mathrm{Fe}, \mathrm{K}$, $\mathrm{Mg}, \mathrm{Mn}, \mathrm{Na}, \mathrm{Ni}, \mathrm{Pb}$, and $\mathrm{Zn}$ (Table 2). In particular, $4 \mathrm{~g}$ of dried, crushed, and sieved soil samples ( $\leq 2 \mathrm{~mm}$ particle size) were weighed into $50-\mathrm{mL}$ polypropylene Digestion Cups (Environmental Express, Charleston, South Carolina, USA), and $45 \mathrm{~mL}$ of Mehlich-3 extracting solution was added. The cups were handled and shaken in the same manner as for $\mathrm{pH}$. Filtermate ${ }^{\circledR}$ filters (Environmental Express, Charleston, South Carolina, USA) were inserted and carefully pressed through the liquid to leave the clear supernatant above the filter. These samples were presented to the Agilent AA240FS and analyzed for the panel of elements presented above. 


\section{Low $=0.1-3.9 \mathrm{dS} \mathrm{m}^{-1}$

\begin{tabular}{|c|c|c|c|c|c|c|c|c|c|c|c|c|c|c|c|c|c|}
\hline DN17 & NM6 & RuOlive & NC14104 & NC14104 & RuOlive & NC14106 & & & Robusta & NC14106 & & & & & & & \\
\hline DN5 & NC14104 & NC14106 & $\underline{\mathrm{NM} 6}$ & NM6 & $\underline{\mathrm{NM} 6}$ & DN17 & & & NC14104 & NM2 & & & & & DN17 & & \\
\hline NC14104 & RuOlive & $\underline{\mathrm{NM} 2}$ & RuOlive & RuOlive & NM2 & $\underline{\text { DN17 }}$ & DN182 & & & & & & & & NM6 & & \\
\hline$\underline{\text { DN5 }}$ & RuOlive & NM2 & $\mathrm{NC}_{14104} 4$ & DN17 & RuOlive & NC14104 & Robusta & NC14106 & & & & NC14106 & & & Robusta & 5 DN17 & \\
\hline NC14106 & NM2 & NM6 & $\underline{\text { NM6 }}$ & DN182 & NC14104 & DN182 & DN182 & RuOlive & & Robusta & Robusta & & & & RuOlive & DN17 & \\
\hline$\underline{\mathrm{NM} 6}$ & NM6 & DN5 & NC14106 & DN17 & DN5 & $\underline{\mathrm{NM} 2}$ & DN5 & & & DN5 & DN17 & NC14106 & $\underline{\mathrm{NM} 2}$ & DN182 & NM6 & & \\
\hline NM2 & DN182 & NM2 & $\underline{N C 14104}$ & NM6 & DN5 & DN5 & & & RuOlive & RuOlive & $\underline{\text { DN5 }}$ & & RuOlive & & $\frac{\text { RuOlive }}{11}$ & & \\
\hline$\underline{\text { DN182 }}$ & ${ }_{8}^{\text {DN182 }}$ & $\underline{\text { NM6 }}$ & DN182 & NC14106 & $\underline{\text { DN5 }}$ & NC14106 & Robusta & NC14104 & DN182 & Robusta & NM6 & & $\mathrm{NC14104}$ & & Robusta & & \\
\hline$\underline{\text { DN17 }}$ & DN182 & NC14106 & Robusta & NC14106 & NM6 & Robusta & NC14106 & DN5 & NC14106 & & & RuOlive & Robusta & DN5 & & & \\
\hline NM6 & DN5 & DN182 & NC14106 & Robusta & $\underline{\mathrm{NM} 2}$ & DN17 & 2 NM6 & & & & & & & & & & \\
\hline NC14104 & NC14106 & RuOlive & RuOlive & 3NC14104 & $\underline{\text { NM2 }}$ & DN5 & RuOlive & DN17 & & & & & & & & & \\
\hline DN17 & DN182 & \begin{tabular}{|l} 
DN182 \\
\end{tabular} & DN17 & DN182 & DN5 & NM2 & NC14104 & NC14106 & DN17 & DN182 & NC14104 & & & & & N & 2 \\
\hline Robusta & $\underline{\text { Robusta }}$ & DN5 & NC14104 & NM2 & $\underline{\mathrm{NM} 2}$ & NC14104 & & & & & & Robusta & NC14104 & 5 NC14106 & & & \\
\hline NC14104 & DN182 & NM2 & NC14106 & DN182 & $\underline{\text { DN5 }}$ & & & & & & & & & & DN17 & & \\
\hline DN17 & Robusta & RuOlive & Robusta & DN17 & Robusta & & & & & & DN17 & RuOlive & & & & $\mathrm{NC} 14104$ & DN182 \\
\hline NM2 & NM2 & Robusta & DN182 & NC14106 & NM6 & & & & & 18 & NM2 & NM6 & & & DN5 & Robusta & \\
\hline & DN17 & DN5 & NM2 & RuOlive & NM2 & Robusta & & & DN17 & NM6 & NM2 & & DN5 & & NM6 & NM6 & NC14104 \\
\hline & & & & & & & & & & & NC14106 & RuOlive & & & DN5 & & \\
\hline
\end{tabular}

Figure 2. Field map showing locations of eight poplar clones and Russian Olive (Elaeagnus angustifolia L.) established on low- (blue), medium- (gray), and high-salinity (green) soils in North Dakota, USA ( $n=7$ trees per soil treatment $\times$ genotype combination). Black circles with numbers indicate soil sampling points ( $n=6$ samples per soil treatment). Leaves were sampled for phytoextraction potential from genotypes that are underlined ( $n=3$ trees per soil treatment $\times$ genotype combination). See Table 1 for genotype information. Dotted cells indicate areas where planting was not possible given the presence of aboveground debris and/or where salinity of the dotted cell was not needed as a planting site (see Figure 1).

Table 1. Mean value $( \pm$ standard error; $n=63)$ for soil salinity $\left(\mathrm{dS} \mathrm{m}^{-1}\right)$ during eight sampling dates in a study testing the survival, growth, and phytoextraction potential of hybrid poplar in North Dakota, USA. Initial soil salinity values were categorized into three treatment levels for data analyses: low ( 0.1 to $\left.3.9 \mathrm{dS} \mathrm{m}^{-1}\right)$, medium ( 4.0 to $\left.5.9 \mathrm{dS} \mathrm{m}^{-1}\right)$, and high $\left(6.0\right.$ to $\left.10.0 \mathrm{dS} \mathrm{m}^{-1}\right)$. The column labeled 'Overall' represents the overall mean averaged across all treatment levels $(n=189)$.

\begin{tabular}{ccccc}
\hline \multicolumn{5}{c}{ Salinity Treatment } \\
\hline Date & Low & Medium & High & Overall \\
\hline 20 May 2014 & $1.89 \pm 0.12$ & $4.87 \pm 0.07$ & $7.73 \pm 0.15$ & $4.83 \pm 0.19$ \\
3 July 2014 & $1.79 \pm 0.13$ & $4.26 \pm 0.12$ & $6.31 \pm 0.19$ & $4.12 \pm 0.16$ \\
15 July 2014 & $1.67 \pm 0.12$ & $3.61 \pm 0.13$ & $5.87 \pm 0.16$ & $3.71 \pm 0.15$ \\
27 August 2014 & $1.35 \pm 0.10$ & $3.08 \pm 0.11$ & $4.72 \pm 0.14$ & $3.05 \pm 0.12$ \\
22 October 2014 & $1.19 \pm 0.09$ & $2.77 \pm 0.09$ & $3.89 \pm 0.17$ & $2.62 \pm 0.11$ \\
8 July 2015 & $1.22 \pm 0.09$ & $2.74 \pm 0.11$ & $4.02 \pm 0.17$ & $2.66 \pm 0.11$ \\
21 June 2016 & $1.21 \pm 0.09$ & $2.14 \pm 0.11$ & $3.46 \pm 0.16$ & $2.27 \pm 0.10$ \\
12 October 2016 & $1.11 \pm 0.09$ & $1.43 \pm 0.11$ & $2.53 \pm 0.12$ & $1.47 \pm 0.07$ \\
\hline
\end{tabular}


Table 2. Mean value ( \pm standard error; $n=6$ ) for soil $\mathrm{pH}$, electrical conductivity (EC; $\mathrm{dS} \mathrm{m}^{-1}$ ), and metals in a study testing the survival, growth, chloride, and phytoextraction potential of hybrid poplar in North Dakota, USA. Initial soil salinity values were categorized into three treatment levels for data analyses: low ( 0.1 to $3.9 \mathrm{dS} \mathrm{m}^{-1}$ ), medium ( 4.0 to $\left.5.9 \mathrm{dS} \mathrm{m}^{-1}\right)$, and high $\left(6.0\right.$ to $\left.10.0 \mathrm{dS} \mathrm{m}^{-1}\right)$. The column labeled 'Overall' represents the overall mean averaged across all treatment levels $(n=18)$. Soils were classified as Harriet loam. See Materials and Methods for details about analytical methods.

\begin{tabular}{|c|c|c|c|c|}
\hline \multicolumn{5}{|c|}{ Salinity Treatment } \\
\hline Parameter & Low & Medium & High & Overall \\
\hline $\mathrm{pH}$ & $7.01 \pm 0.23$ & $7.68 \pm 0.17$ & $8.02 \pm 0.15$ & $7.57 \pm 0.14$ \\
\hline EC & $0.96 \pm 0.28$ & $2.98 \pm 0.54$ & $3.56 \pm 0.97$ & $2.50 \pm 0.45$ \\
\hline & \multicolumn{4}{|c|}{$\mathrm{g} \mathrm{kg}^{-1}$} \\
\hline Calcium (Ca) & $3.56 \pm 0.18$ & $4.09 \pm 0.70$ & $5.30 \pm 0.53$ & $4.32 \pm 0.33$ \\
\hline Chloride $\left(\mathrm{Cl}^{-}\right)$ & $0.27 \pm 0.04$ & $0.76 \pm 0.18$ & $1.33 \pm 0.28$ & $0.79 \pm 0.15$ \\
\hline Magnesium (Mg) & $1.20 \pm 0.08$ & $1.99 \pm 0.18$ & $1.89 \pm 0.17$ & $1.69 \pm 0.12$ \\
\hline \multirow[t]{2}{*}{ Sodium $(\mathrm{Na})$} & $1.28 \pm 0.40$ & $3.91 \pm 0.39$ & $5.86 \pm 0.72$ & $3.68 \pm 0.54$ \\
\hline & \multicolumn{4}{|c|}{$\mathrm{mg} \mathrm{kg}^{-1}$} \\
\hline Aluminum (Al) & $533.07 \pm 44.86$ & $407.26 \pm 70.97$ & $256.94 \pm 58.99$ & $399.09 \pm 42.21$ \\
\hline Cadmium (Cd) & $0.08 \pm 0.03$ & $0.06 \pm 0.03$ & $0.10 \pm 0.02$ & $0.08 \pm 0.01$ \\
\hline Cobalt $(\mathrm{Co})$ & $1.69 \pm 0.11$ & $2.09 \pm 0.23$ & $1.75 \pm 0.20$ & $1.84 \pm 0.11$ \\
\hline Chromium (Cr) & $0.54 \pm 0.12$ & $0.50 \pm 0.08$ & $0.52 \pm 0.10$ & $0.52 \pm 0.06$ \\
\hline Copper $(\mathrm{Cu})$ & $2.48 \pm 0.79$ & $2.49 \pm 0.58$ & $2.77 \pm 0.56$ & $2.58 \pm 0.36$ \\
\hline Iron $(\mathrm{Fe})$ & $374.21 \pm 19.44$ & $368.29 \pm 8.83$ & $344.41 \pm 23.33$ & $362.30 \pm 10.38$ \\
\hline Potassium (K) & $711.86 \pm 74.87$ & $572.25 \pm 22.67$ & $474.99 \pm 24.69$ & $586.37 \pm 34.87$ \\
\hline Manganese (Mn) & $187.01 \pm 21.23$ & $227.24 \pm 24.82$ & $181.12 \pm 20.03$ & $198.46 \pm 12.99$ \\
\hline Nickel (Ni) & $22.62 \pm 2.08$ & $28.06 \pm 2.76$ & $24.79 \pm 2.97$ & $25.16 \pm 1.53$ \\
\hline Lead $(\mathrm{Pb})$ & $2.01 \pm 0.60$ & $2.33 \pm 0.70$ & $3.12 \pm 0.67$ & $2.49 \pm 0.37$ \\
\hline Zinc (Zn) & $4.83 \pm 0.58$ & $4.16 \pm 0.30$ & $3.64 \pm 0.23$ & $4.21 \pm 0.25$ \\
\hline
\end{tabular}

\subsection{Plant Material and Experimental Design}

Eight hybrid poplar clones [Populus deltoides Bartr. ex Marsh. $\times$ P. nigra L. 'Robusta', 'DN17', 'DN182', 'DN5'; P. deltoides $\times$ P. maximowiczii A. Henry 'NC14104', 'NC14106'; P. nigra $\times$ P. maximowiczii 'NM2', 'NM6'] and one Russian olive (Elaeagnus angustifolia L.) accession were tested (Table 3). For consistency with hybrid poplar clones, Russian olive is referred to as 'RuOlive' in the Results. 'Robusta' and 'DN17' are the same genotype but they came from different nursery sources (i.e., hence their different nomenclature), and they were analyzed as two different clones to evaluate performance of planting stock from these two sources. 'Robusta' was acquired from Big Sioux Nursery, Watertown, South Dakota, USA, while all other hybrid poplar clonal material (including 'DN17') came from the USDA Forest Service, Institute for Applied Ecosystem Studies in Rhinelander, Wisconsin, USA from one-year-old coppice shoots collected from stoolbeds at Hugo Sauer Nursery. All hybrid poplar consisted of $25.4 \mathrm{~cm}$ dormant, unrooted cuttings that were grown in $10.16-\times 10.16-\times 35.56-\mathrm{cm}$ TP414 Treepots (Stuewe and Sons, Inc., Tangent, Oregon, USA) for one growing season at the USDA Natural Resources Conservation Service, Bismarck Plant Materials Center in Bismarck, North Dakota, USA. Russian olive was bare root conservation grade stock purchased the year of establishment from Lincoln Oakes Nursery in Bismarck, North Dakota, USA.

On 10 June 2014, seven trees of each genotype were planted from the TP414 Treepots (hybrid poplars) and as bare root stock (Russian Olive) in a completely random experimental design at 3.05$\times$ 3.05-m spacing within each soil salinity treatment (i.e., 189 trees were tested). Given the soil heterogeneity described above, some trees did not have full tree competition on all sides, resulting in spacing that was greater than $9.3 \mathrm{~m}^{2}$ per tree (Figure 2). The depth to the bottom of each root ball was $30.48 \mathrm{~cm}$. Due to the sticky nature of the soils, $0.007 \mathrm{~m}^{3}$ of Mandan silt loam soil was used to backfill each planting hole. Once planted, $1.52 \mathrm{~m}$ Tubex ${ }^{\circledR}$ tree shelters (Tubex, Old Hickory, Tennessee, USA) were installed on each tree for protection from white-tailed deer (Odocoileus virginianus Zimmermann) (Figure 1). A $1.83 \times 1.83 \mathrm{~m}$ square of $90.7 \mathrm{~g}$ DeWitt Sunbelt woven ground cover (DeWitt Company, Sikeston, Missouri, USA) was installed around each tree to eliminate competing vegetation (Figure 1). 
Table 3. Populus genomic groups and clones tested on low-, medium-, and high-salinity soils in North Dakota, USA. Russian olive (Elaeagnus angustifolia L.) (accession number 9019582) was grown as an experimental control.

\begin{tabular}{ccc}
\hline Accession $^{\text {a }}$ & Clone & Genomic Group $^{\mathbf{b}}$ \\
\hline 9094432 & Robusta & 'DN' P. deltoides $\times$ P. nigra \\
9094423 & DN17 & “ \\
9094422 & DN182 & \\
9094421 & DN5 & 'DM' P. deltoides $\times$ P. maximowiczii \\
9094424 & NC14104 & "NM' P. nigra $\times$ P. maximowiczii \\
9094425 & NC14106 & “ \\
9094426 & NM2 & NM6 \\
9094427 & N & \\
\hline
\end{tabular}

a Accession numbers from the USDA-Natural Resources Conservation Service Bismarck Plant Materials Center, Bismarck, North Dakota, USA. ${ }^{\mathrm{b}}$ Sections and authorities are: Aigeiros Duby-P. deltoides Bartr. ex Marsh, P. nigra L. Tacamahaca Spach-P. maximowiczii A. Henry.

\subsection{Data Collection and Analysis}

Survival and tree height $(\mathrm{m})$ were determined following first, second, third, and fourth year budset. Height was measured from the base of the tree to the tip of the terminal bud. Per a landowner maintenance agreement, Russian olive was removed after the third growing season to prevent its spread onto the landscape. Thus, survival and height data were not available for Russian olive during year four.

On 27 August 2014 leaves from leaf plastochron index (LPI) 5, 10, and 15 [30] were collected from three trees per soil treatment $\times$ genotype combination (i.e., 81 trees were tested) (Figure 2). The leaves were brought back to the USDA Forest Service, Institute for Applied Ecosystem Studies in Rhinelander, Wisconsin, USA, for evaluation of phytoextraction potential via laboratory analyses of $\mathrm{Al}, \mathrm{Ca}, \mathrm{Cd}, \mathrm{Fe}, \mathrm{K}$, $\mathrm{Mg}$, Mn, $\mathrm{Na}$, and $\mathrm{Zn}$ using an Agilent AA240FS fast sequential atomic absorption spectrometer (Agilent Technologies, Santa Clara, California, USA). In particular, leaf tissue was ground with a Cyclotec 1093 sample mill (Foss North America, Inc., Eden Prairie, Minnesota, USA) using a 20-mesh screen. For each tree, 100 to $400 \mathrm{mg}$ of ground leaf tissue was placed in 50-mL polypropylene Digestion Cups (Environmental Express, Charleston, South Carolina, USA), and $7 \mathrm{~mL}$ of $10.6-\mathrm{N}$ nitric acid $\left(\mathrm{HNO}_{3}\right)$ was added. The cups were placed at room temperature under an operating fume hood for at least $30 \mathrm{~min}$ to initiate pre-digestion. One or more empty tubes were included in each digestion set to serve as "blanks". After a minimum of $30 \mathrm{~min}$, under an operating fume hood, the digestion cups were placed into a Smartblock $125^{\circledR}$ digester (Columbia Analytical Instruments, Inc., Irmo, South Carolina, USA) that was pre-heated to $125^{\circ} \mathrm{C}$. The samples were digested for at least $45 \mathrm{~min}$, watching from that point to be sure they were not reduced to dryness. When all samples were reduced to 2 to $5 \mathrm{~mL}$ and were clear, the cups were removed from the block and cooled to room temperature. After a minimum of $15 \mathrm{~min}, 45 \mathrm{~mL}$ of water purified with a RODI-T2 reverse osmosis plus Type II DI system (Aqua Solutions, Jasper, GA, USA) was added to the digestion cups that were then capped and inverted several times to thoroughly mix the contents before being transferred to new, clean digestion cups. The new cups were brought to $50 \mathrm{~mL}$ volume with purified water, capped, and inverted to mix. Filtermate ${ }^{\circledR}$ filters (Environmental Express, Charleston, SC, USA) were inserted and carefully pressed through the liquid to leave the clear supernatant above the filter. These samples were presented to the Agilent AA240FS and analyzed for the panel of elements presented above.

All height and phytoextraction data were subjected to analyses of variance (ANOVA) and analyses of means (ANOM) according to SAS ${ }^{\circledR}$ (PROC GLM; PROC ANOM; SAS INSTITUTE, INC., Cary, North Carolina, USA) assuming the aforementioned completely random design including the main effects of soil salinity treatment (fixed), genotype (fixed), and their interactions. Fisher's protected least significant difference (LSD) was used to separate means of main effects at a probability level of $p<0.05$. 


\section{Results}

\subsection{Survival}

Annual survival rates across all soil salinity treatments and genotypes decreased approximately $20 \%$ each year, with overall means ranging from $97 \%$ after the first growing season to $40 \%$ at four years after planting (Figure 3). First-year survival rates were relatively stable across treatment $\times$ genotype interactions; six of the nine genotypes exhibited 100\% survival in all three soil treatments (Figure 3). Soil salinity impacted hybrid poplar clone 'NC14106' (P. deltoides $\times$ P. maximowiczii) the most, with survival rates decreasing from $100 \%$ in low-salinity soils to $86 \%$ and $71 \%$ in medium- and high-salinity treatments, respectively. Fourteen percent of the two remaining clones, 'DN182' (P. deltoides $\times$ P. nigra) and 'DN5' ( $P$. deltoides $\times P$. nigra), died during the first year when planted in the high-salinity soils, while 'DN182' also had this mortality rate for the medium salinity treatment.
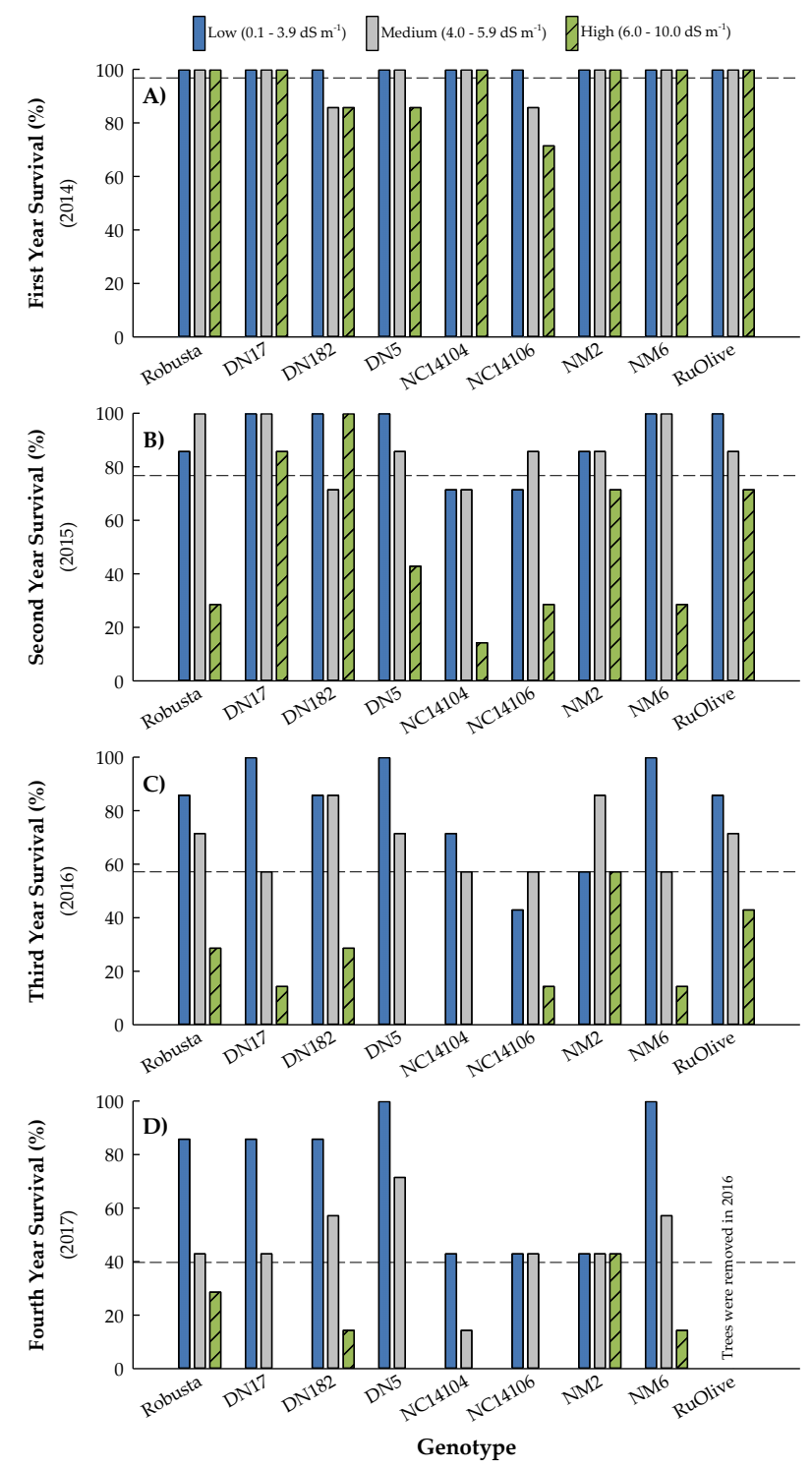

Figure 3. Mean survival $(n=7)$ after the first $(\mathbf{A})$, second $(\mathbf{B})$, third $(\mathbf{C})$, and fourth (D) growing seasons of eight hybrid poplar clones and Russian Olive (Elaeagnus angustifolia L.) grown on soils varying in salinity in North Dakota, USA. Soil treatments were based on initial values and included low (0.1 to $\left.3.9 \mathrm{dS} \mathrm{m}^{-1}\right)$, medium (4.0 to $5.9 \mathrm{dS} \mathrm{m}^{-1}$ ), and high $\left(6.0\right.$ to $\left.10.0 \mathrm{dS} \mathrm{m}^{-1}\right)$ ] salinity ranges. The dashed line represents the overall mean. Per a landowner maintenance agreement, all Russian olive trees were removed in 2016. 
After the second growing season, survival ranged from $52 \%$ (high salinity) to $90 \%$ (low salinity) for salinity treatments and 52\% ('NC14104'; P. deltoides $\times$ P. maximowiczii) to 95\% ('DN17'; P. deltoides $\times$ P. nigra) for genotypes (Figure 3). Survival for Russian olive (Elaeagnus angustifolia L. 'RuOlive') in year two was similar to 'NC14106' in year one, with 100\% of its trees surviving in low-salinity soil followed by $86 \%$ and $71 \%$ in medium- and high-salinity treatments, respectively. There was an inverse relationship between survival and salinity levels, with most hybrid poplar clones having substantially lower survival in the high-salinity soils, though some genotypes were less impacted. For example, 'DN182' had 100\% survival in the high-salinity treatment despite $29 \%$ of its trees dying in the medium-salinity soils. All trees planted in low- and medium-salinity soils survived for clone 'DN17', and its trees of the high-salinity treatment had $86 \%$ survival, which was the best performance across all genotypes and soil treatments in year two.

Furthermore, noticeable mortality occurred during the third growing season, with $43 \%$ of the trees dying across treatments and genotypes during that year (Figure 3). Survival ranged from $22 \%$ (High treatment) to 81\% (Low) for salinity treatments, and 38\% ('NC14106') to 67\% ('DN182', 'RuOlive', 'NM2' (P. nigra $\times$ P. maximowiczii)) for genotypes. All of the 'DN5' and 'NC14104' trees planted in the high-salinity soils died, and survival decreased to $14 \%$ for 'DN17' and 'NC14106' for this treatment. In contrast, trees of 'NM2' were not impacted by the high-salinity soils relative to those with low salinity, having survival rates of $57 \%$ in both treatments.

After the fourth growing season, survival ranged from 11\% (High) to 65\% (Low) for salinity treatments and 19\% ('NC14104') to 57\% ('DN5', 'NM6' (P. nigra $\times$ P. maximowiczii)) for genotypes (Figure 3). Distinct survival patterns emerged during year four. First, in addition to 'DN5' and 'NC14104' that exhibited complete mortality in high-salinity soils during year 3, all trees of clones 'DN17' and 'NC14106' died in this treatment during the fourth growing season. Second, two clones, 'Robusta' (P. deltoides $\times$ P. nigra) and 'NM6' had stable survival rates from years two through four, with those in the last two years of study being nearly identical (within each genotype). Third, of all the genotypes tested, 'NM2' exhibited the greatest survival in high-salinity soils (i.e., 43\%), which was equal to its survival rate in both the low- and medium-salinity soils at the end of the study.

\subsection{Height Growth}

The treatment $\times$ genotype interaction was negligible for first- and second-year height $(p=0.2405$, $p=0.5738$, respectively), yet the treatment $(p<0.0001)$ and genotype $(p<0.0001)$ main effects were both significant for these heights (Table 4). After the first growing season, low-salinity soils had the significantly largest trees that were $9 \%$ and 16\% taller than trees in the medium and high salinity treatments (which differed from each other), respectively (Table 5). Height of the low-treatment trees was $8 \%$ greater than the overall mean, while high-treatment trees were $9 \%$ shorter than the overall mean. Similarly, second-year height was significantly greatest for the low salinity treatment, where its trees were $9 \%$ and $36 \%$ taller than trees in the medium and high salinity treatments (which differed from each other), respectively (Table 5). For the genotype main effect, one-year-old trees ranged in height from $0.81 \pm 0.03$ ('RuOlive') to $1.72 \pm 0.05 \mathrm{~m}$ ('DN5'), with an overall mean of $1.50 \pm 0.02 \mathrm{~m}$ (Figure 4). There were no differences in height within hybrid poplar genomic groups, and clones exhibited similar values, which were all $49 \%$ significantly taller than for 'RuOlive'. Height was much more variable in year two, ranging from $1.44 \pm 0.13$ ('RuOlive') to $2.13 \pm 0.15 \mathrm{~m}$ ('DN5'), with an overall mean of $1.79 \pm 0.04 \mathrm{~m}$ (Figure 4). Clones 'Robusta', 'DN5', and 'NM6' had the greatest height among clones, and there were differences among genotypes within genomic groups. For example, 'DN182' trees were $20 \%$ shorter than for the other P. deltoides $\times$ P. nigra clones. Likewise, 'NM6' had $28 \%$ taller trees than 'NM2' within the P. nigra $\times$ P. maximowiczii genomic group. In contrast, 'NC14014' and 'NC14016' exhibited identical second-year height (Figure 4). 
Table 4. Probability values from analyses of variance comparing height and leaf phytoextraction potential of eight hybrid poplar clones and Russian olive (Elaeagnus angustifolia $\mathrm{L}$.) ( $G=$ nine genotypes) established on low-, medium-, and high-salinity soils ( $T=$ three soil treatments) in North Dakota, USA. Significant values listed in bold were compared in the Results and illustrated in Table 5 and Figures 4-6.

\begin{tabular}{cccc}
\hline & \multicolumn{3}{c}{ Source of Variation } \\
\hline Parameter & $\mathbf{T}$ & $\mathbf{G}$ & $\mathbf{T} \times \mathbf{G}$ \\
\hline & Height & & \\
(2014) First Year & $<\mathbf{0 . 0 0 0 1}$ & $<\mathbf{0 . 0 0 0 1}$ & 0.2405 \\
(2015) Second Year & $<\mathbf{0 . 0 0 0 1}$ & $<\mathbf{0 . 0 0 0 1}$ & 0.5738 \\
(2016) Third Year & $<0.0001$ & $<0.0001$ & $\mathbf{0 . 0 4 8 6}$ \\
(2017) Fourth Year & $<0.0001$ & 0.0002 & $<\mathbf{0 . 0 0 0 1}$ \\
& Leaf Phytoextraction & \\
Aluminum (Al) & $\mathbf{0 . 0 0 1 1}$ & $<\mathbf{0 . 0 0 0 1}$ & 0.6113 \\
Calcium $(\mathrm{Ca})$ & $\mathbf{0 . 0 0 0 4}$ & $<\mathbf{0 . 0 0 0 1}$ & 0.3609 \\
Cadmium $(\mathrm{Cd})$ & 0.0827 & $<\mathbf{0 . 0 0 0 1}$ & 0.8508 \\
Iron $(\mathrm{Fe})$ & $\mathbf{0 . 0 2 3 9}$ & $<\mathbf{0 . 0 0 0 1}$ & 0.2088 \\
Potassium $(\mathrm{K})$ & $\mathbf{0 . 0 2 4 7}$ & 0.8734 & 0.1237 \\
Magnesium $(\mathrm{Mg})$ & $<\mathbf{0 . 0 0 0 1}$ & $<\mathbf{0 . 0 0 0 1}$ & 0.3731 \\
Manganese $(\mathrm{Mn})$ & $\mathbf{0 . 0 0 1 0}$ & $\mathbf{0 . 0 0 1 9}$ & 0.7696 \\
Sodium $(\mathrm{Na})$ & $<0.0001$ & $<0.0001$ & $\mathbf{0 . 0 0 4 4}$ \\
Zinc $(\mathrm{Zn})$ & 0.4731 & $\mathbf{0 . 0 0 0 8}$ & 0.2629 \\
\hline
\end{tabular}

Table 5. Mean height ( $n=33$ to 63) and leaf phytoextraction $(n=27)$ ( \pm standard error) across eight hybrid poplar clones and Russian Olive (Elaeagnus angustifolia L.) for initial soil salinity treatment main effects [low $\left(0.1\right.$ to $\left.3.9 \mathrm{dS} \mathrm{m}^{-1}\right)$, medium $\left(4.0\right.$ to $\left.5.9 \mathrm{dS} \mathrm{m}^{-1}\right)$, and high $\left(6.0\right.$ to $\left.10.0 \mathrm{dS} \mathrm{m}^{-1}\right)$ ] in a study testing the survival, growth, and phytoextraction potential of hybrid poplar in North Dakota, USA. Means with different letters within rows were different at $p<0.05$, while those labeled with an asterisk $\left(^{*}\right)$ were different than the overall mean at $p<0.05$. Leaves were sampled on 27 August 2014. See Figure 2 for locations of trees from which leaves were sampled.

\begin{tabular}{|c|c|c|c|c|c|c|c|}
\hline \multicolumn{8}{|c|}{ Salinity Treatment } \\
\hline Parameter & Low & & Medium & & High & & Overall \\
\hline & \multicolumn{7}{|c|}{ Height $(m)$} \\
\hline (2014) First Year & $1.63 \pm 0.04$ & $a^{*}$ & $1.48 \pm 0.04$ & $b$ & $1.37 \pm 0.04$ & $c^{*}$ & $1.50 \pm 0.02$ \\
\hline \multirow[t]{2}{*}{ (2015) Second Year } & $2.03 \pm 0.07$ & $z^{*}$ & $1.84 \pm 0.06$ & $\mathrm{y}$ & $1.31 \pm 0.05$ & $x^{*}$ & $1.79 \pm 0.04$ \\
\hline & \multicolumn{7}{|c|}{ Leaf phytoextraction $\left(g \mathrm{~kg}^{-1}\right)$} \\
\hline Calcium (Ca) & $10.41 \pm 0.65$ & $b^{*}$ & $12.77 \pm 0.87$ & $\mathrm{a}$ & $14.16 \pm 0.92$ & $a^{*}$ & $12.44 \pm 0.50$ \\
\hline \multirow[t]{2}{*}{ Magnesium (Mg) } & $3.80 \pm 0.20$ & $\mathrm{y}^{*}$ & $5.56 \pm 0.38$ & $\mathrm{z}$ & $5.63 \pm 0.31$ & $\mathrm{z}$ & $5.00 \pm 0.20$ \\
\hline & \multicolumn{7}{|c|}{ Leaf phytoextraction $\left(m g \mathrm{~kg}^{-1}\right)$} \\
\hline Aluminum (Al) & $198.94 \pm 20.11$ & $b^{*}$ & $278.87 \pm 21.09$ & $\mathrm{a}$ & $271.37 \pm 21.13$ & a & $249.72 \pm 12.51$ \\
\hline Iron $(\mathrm{Fe})$ & $67.50 \pm 5.30$ & $\mathrm{yx}$ & $92.36 \pm 11.22$ & $\mathrm{z}$ & $75.21 \pm 5.73$ & zy & $78.35 \pm 4.65$ \\
\hline Potassium (K) & $28.12 \pm 1.01$ & $\mathrm{~b}$ & $28.53 \pm 1.20$ & $\mathrm{~b}$ & $32.79 \pm 1.70$ & $a *$ & $29.81 \pm 0.80$ \\
\hline Manganese (Mn) & $53.38 \pm 5.13$ & $\mathrm{y}^{*}$ & $76.55 \pm 4.69$ & $\mathrm{z}$ & $77.25 \pm 6.06$ & $\mathrm{z}$ & $69.06 \pm 3.28$ \\
\hline
\end{tabular}




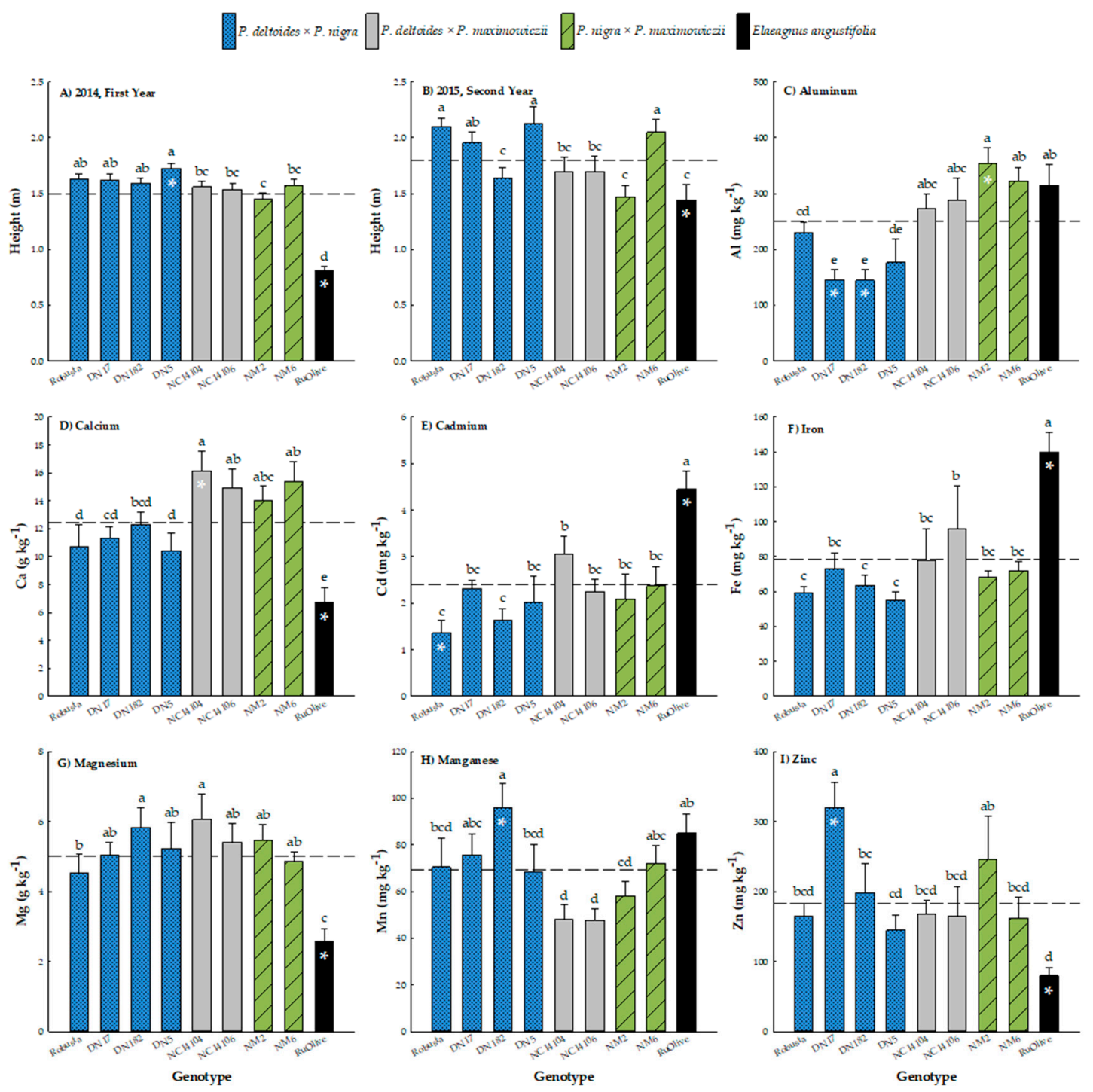

Figure 4. Mean height ( \pm standard error) after the first $(\mathbf{A})$ and second $(\mathbf{B})$ growing seasons, as well as leaf phytoextraction ( \pm standard error) of aluminum $(\mathrm{Al})(\mathbf{C})$, calcium $(\mathrm{Ca})(\mathrm{D})$, cadmium $(\mathrm{Cd})(\mathrm{E})$, iron $(\mathrm{Fe})(\mathbf{F})$, magnesium $(\mathrm{Mg})(\mathrm{G})$, manganese $(\mathrm{Mn})(\mathbf{H})$, and zinc $(\mathrm{Zn})(\mathbf{I})$ of eight hybrid poplar clones and Russian Olive (Elaeagnus angustifolia L.) grown on soils varying in salinity in North Dakota, USA. The dashed line represents the overall mean, while bars with asterisks indicate means that differ from the overall mean at $p<0.05$. Bars with different letters were different according to Fisher's protected least significant difference (LSD) at $p<0.05$.

Treatment $\times$ genotype interactions were significant for height at three $(p=0.0486)$ and four $(p<0.0001)$ years after planting (Table 4$)$. After the third growing season, height ranged from $0.91 \pm 0.00$ ('NC14106' High) to $3.04 \pm 0.16 \mathrm{~m}$ ('DN5' Low), with an overall mean of $2.23 \pm 0.04 \mathrm{~m}$ (Figure 5). Although all of the high-salinity trees died for 'DN5' and 'NC14104', height did not differ for the other treatments within either of these clones. Similarly, there were no differences among salinity treatments for 'DN182', 'NC14106', 'NM2', 'NM6' nor 'RuOlive'. In contrast, trees of 'DN17' grew $53 \%$ taller in low- versus high-salinity soils. Likewise, trees in both low and medium salinity treatments were significantly taller than those in high-salinity soils, having 53\% and 50\% greater height, respectively (Figure 5). In the fourth growing season, height ranged from $0.61 \pm 0.16$ ('Robusta' High) to $3.28 \pm 0.20 \mathrm{~m}$ ('DN5' Low), with an overall mean of $2.44 \pm 0.09 \mathrm{~m}$ (Figure 5). As noted above, only four of the eight clones tested (i.e., 'RuOlive' was removed after the third growing season per a landowner maintenance agreement) were still alive on the high salinity treatment in year four: 'Robusta', 'DN182', 
'NM2', and 'NM6'. Of those, height was only significantly different for 'Robusta', wherein trees with the same height for low and medium treatments grew $78 \%$ taller than those in the high salinity soils.

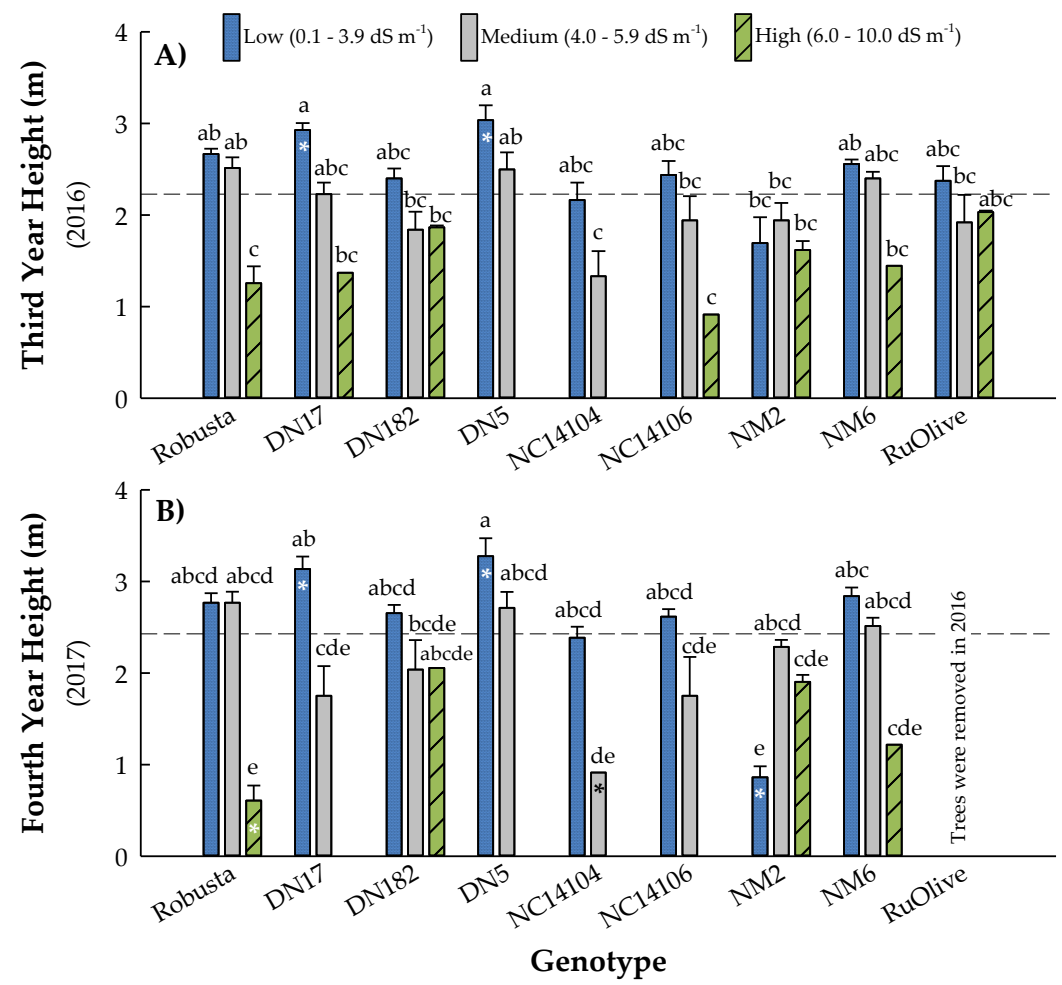

Figure 5. Mean height ( \pm standard error) after the third (A) and fourth (B) growing seasons of eight hybrid poplar clones and Russian Olive (Elaeagnus angustifolia L.) grown on soils varying in salinity in North Dakota, USA. Soil treatments included low $\left(0.1\right.$ to $\left.3.9 \mathrm{dS} \mathrm{m}^{-1}\right)$, medium $\left(4.0\right.$ to $\left.5.9 \mathrm{dS} \mathrm{m}^{-1}\right)$, and high ( 6.0 to $10.0 \mathrm{dS} \mathrm{m}^{-1}$ ) initial salinity ranges. The dashed line represents the overall mean, while bars with asterisks indicate means that differ from the overall mean at $p<0.05$. Bars with different letters were different according to Fisher's protected LSD at $p<0.05$. Per a landowner maintenance agreement, all Russian olive trees were removed in 2016.

\subsection{Leaf Phytoextraction}

The treatment $\times$ genotype interaction was negligible for phytoextraction of $\mathrm{Al}, \mathrm{Ca}, \mathrm{Cd}, \mathrm{Fe}, \mathrm{K}, \mathrm{Mg}$, $\mathrm{Mn}$, and $\mathrm{Zn}$, yet the treatment main effect was significant for all of these metals $(p<0.05)$ except $\mathrm{Cd}$ and $\mathrm{Zn}$ (Table 4). Uptake of Al was greatest on medium- and high-salinity soils that were not different from one another but were $28 \%$ greater than the low salinity treatment, which was $20 \%$ less than the overall mean (Table 5). Similar trends were shown for $\mathrm{Ca}, \mathrm{Mg}$, and $\mathrm{Mn}$, where the medium and high salinity treatments had $26 \%, 33 \%$, and $31 \%$ more leaf uptake than the low salinity treatment, respectively. Iron uptake was greatest for medium-salinity soils, which were not different from Fe phytoextraction from high-salinity treatments but were $27 \%$ greater than in the low-salinity soils. Lastly, K uptake was $15 \%$ greater in high-salinity soils than either of the other treatments (that did not differ from one another) and $9 \%$ more than the overall mean (Table 5).

Clones differed in their leaf phytoextraction of $\mathrm{Al}, \mathrm{Ca}, \mathrm{Cd}, \mathrm{Fe}, \mathrm{Mg}, \mathrm{Mn}$, and $\mathrm{Zn}(p<0.05)$ (Table 4). The leaf concentration of $\mathrm{Al}$ ranged from $144.41 \pm 19.30$ ('DN182') to $353.12 \pm 28.94 \mathrm{mg} \mathrm{Al} \mathrm{kg}^{-1}$ ('NM2'), with a mean of $249.73 \pm 12.51 \mathrm{mg} \mathrm{Al} \mathrm{kg}^{-1}$ (Figure 4). The P. deltoides $\times P$. nigra clones exhibited $78 \%$ less $\mathrm{Al}$ uptake than the P. deltoides $\times$ P. maximowiczii genotypes, P. nigra $\times$ P. maximowiczii genotypes, and 'RuOlive', which were not different from one another. Clones 'DN17' and 'DN182' had the lowest Al uptake, which was $73 \%$ less than the overall mean. Calcium phytoextraction ranged from $6.71 \pm 1.11$ ('RuOlive') to $16.14 \pm 1.42 \mathrm{~g} \mathrm{Ca} \mathrm{kg}^{-1}$ ('NC14104'), with a mean of $12.44 \pm 0.50 \mathrm{~g} \mathrm{Ca} \mathrm{kg}^{-1}$ (Figure 4). Genotypes segregated into three response groups based on genomic group: 1) clones belonging to 
the $P$. deltoides $\times P$. maximowiczii and $P$. nigra $\times P$. maximowiczii genomic groups exhibited the greatest Ca phytoextraction, 2) P. deltoides $\times$ P. nigra clones had the second highest Ca levels, and 3) 'RuOlive', which had $85 \%$ less Ca uptake than the overall mean, also had significantly less Ca than either of the other response groups. For $\mathrm{Cd}$, leaf concentrations ranged from $1.36 \pm 0.27$ ('Robusta') to $4.45 \pm 0.40 \mathrm{mg}$ $\mathrm{Cd} \mathrm{kg}^{-1}$ ('RuOlive'), with a mean of $2.39 \pm 0.15 \mathrm{mg} \mathrm{Cd} \mathrm{kg}^{-1}$ (Figure 4). In contrast to Ca where Russian olive had the lowest phytoextraction potential, $\mathrm{Cd}$ in the leaves of 'RuOlive' was 31\% ('NC14104') to $69 \%$ ('Robusta') greater than the other clones and $46 \%$ greater than the overall mean. For Fe, leaf concentrations ranged from $55.31 \pm 4.56$ ('DN5') to $140.14 \pm 10.91 \mathrm{mg} \mathrm{Fe} \mathrm{kg}{ }^{-1}$ ('RuOlive'), with a mean of $78.35 \pm 4.65 \mathrm{mg} \mathrm{Fe} \mathrm{kg}^{-1}$ (Figure 4). Similar to the results for $\mathrm{Cd}, \mathrm{Fe}$ in the leaves of 'RuOlive' was 31\% ('NC14106') to $61 \%$ ('DN5') greater than the other clones and $44 \%$ greater than the overall mean. The leaf concentration of $\mathrm{Mg}$ ranged from $2.57 \pm 0.36$ ('RuOlive') to $6.06 \pm 0.72 \mathrm{~g} \mathrm{Mg} \mathrm{kg}^{-1}$ ('NC14104'), with a mean of $5.00 \pm 0.20 \mathrm{~g} \mathrm{Mg} \mathrm{kg}^{-1}$ (Figure 4), which was the opposite trend than that for Cd and Fe. In particular, despite 'DN182' and 'NC14104' having 23\% and 26\% more Mg in their leaves than 'Robusta', respectively, all of the hybrid poplar genotypes exhibited significantly higher Mg concentrations than 'RuOlive', which had 95\% less Mg than the overall mean. Manganese phytoextraction ranged from $47.79 \pm 4.66$ ('NC14106') to $95.82 \pm 10.66 \mathrm{mg} \mathrm{Mn} \mathrm{kg}^{-1}$ ('DN182'), with a mean of $69.06 \pm 3.28 \mathrm{mg} \mathrm{Mn} \mathrm{kg}^{-1}$ (Figure 4). Clones within genomic groups were consistent in their uptake of $\mathrm{Mn}$, with $P$. deltoides $\times$ P. nigra genotypes having the greatest overall concentrations (that were similar to 'RuOlive') followed by P. nigra $\times$ P. maximowiczii clones and then P. deltoides $\times$ P. maximowiczii genotypes. For $\mathrm{Zn}$, leaf concentrations ranged from $80.02 \pm 11.43$ ('RuOlive') to $320.29 \pm 36.09 \mathrm{mg} \mathrm{Zn}$ $\mathrm{kg}^{-1}$ ('DN17'), with a mean of $183.29 \pm 12.98 \mathrm{mg} \mathrm{Zn} \mathrm{kg}^{-1}$ (Figure 4). With the exception of 'DN17' having the greatest $\mathrm{Zn}$ uptake that was $43 \%$ higher than the overall mean and 'RuOlive' with the least $\mathrm{Zn}$ uptake that was $129 \%$ lower than the overall mean, genotypes exhibited relatively uniform phytoextraction of $\mathrm{Zn}$.

The treatment $\times$ genotype interaction was significant for phytoextraction of $\mathrm{Na}(p=0.0044)$ (Table 4). Uptake of Na into the leaves ranged from $0.03 \pm 0.01$ ('NC14106' Low) to $5.88 \pm 0.77 \mathrm{~g} \mathrm{Na}$ $\mathrm{kg}^{-1}$ ('RuOlive' High), with an overall mean of $0.93 \pm 0.17 \mathrm{~g} \mathrm{Na} \mathrm{kg}^{-1}$ (Figure 6). Sodium concentration in the leaves did not differ among treatments within individual hybrid poplar genotypes (Figure 6), yet general trends were similar as with height during years three and four. In particular, the $P$. deltoides $\times P$. nigra clones exhibited substantial within-group variability, with 'DN5' having 70\% lower overall Na uptake than the other clones. In addition, the P. deltoides $\times$ P. maximowiczii clones had the lowest overall Na uptake, that being only $70 \%$ of the overall mean. For P. nigra $\times$ P. maximowiczii clones, 'NM2' had some of the highest Na concentrations for medium- and high-salinity soils of all treatment $\times$ genotype combinations, while 'NM6' had consistent Na for low and medium treatments that were 125\% less than that for the high-salinity soils, albeit not statistically different. 'RuOlive' exhibited the greatest Na phytoextraction, with trees grown in the high-salinity soils taking up to $78 \%$ more Na than those of the low salinity treatment.

\section{Discussion}

In this study, survival, height, and phytoextraction potential of known saline-tolerant hybrid poplar genotypes were compared with that of Russian olive at a field site in Burleigh County, North Dakota, USA that had soils naturally varying in salinity. Overall, hybrid poplars exhibited greater survival and height than Russian olive, and phytoextraction potential depended on specific element $\times$ genotype combinations. It is worth noting, however, that Russian olive, by nature, is substantially shorter than any of the hybrid poplar genotypes tested, regardless of soil conditions. Hybrid poplar survival rates of the current study were consistent with previous reports during the first growing season yet lower than expected during years two through four, wherein survival decreased $20 \%$ per year to an overall survival rate of $40 \%$ at the end of the study. Expected survival rates throughout 10- to 12 -year rotations of poplars are $90 \%$ to $95 \%$ for biomass applications [31,32] and $80 \%$ to $90 \%$ for phytotechnologies [33,34]. For example, in applications that are most similar to the current study 
with respect to salinity, Zalesny et al. [14] reported 78\% survival for eight poplar genotypes that were irrigated with high-salinity landfill leachate (i.e., 6.2 to $9.4 \mathrm{dS} \mathrm{m}^{-1}$ ) for two growing seasons. In a long-term component of that study, 8-year-old companion trees of P. nigra $\times$ P. maximowiczii 'NM2' had $90 \%$ survival [35], which was similar to 14 P. deltoides clones receiving tertiary treated municipal wastewater at 27 months after planting in Florida, USA [36].

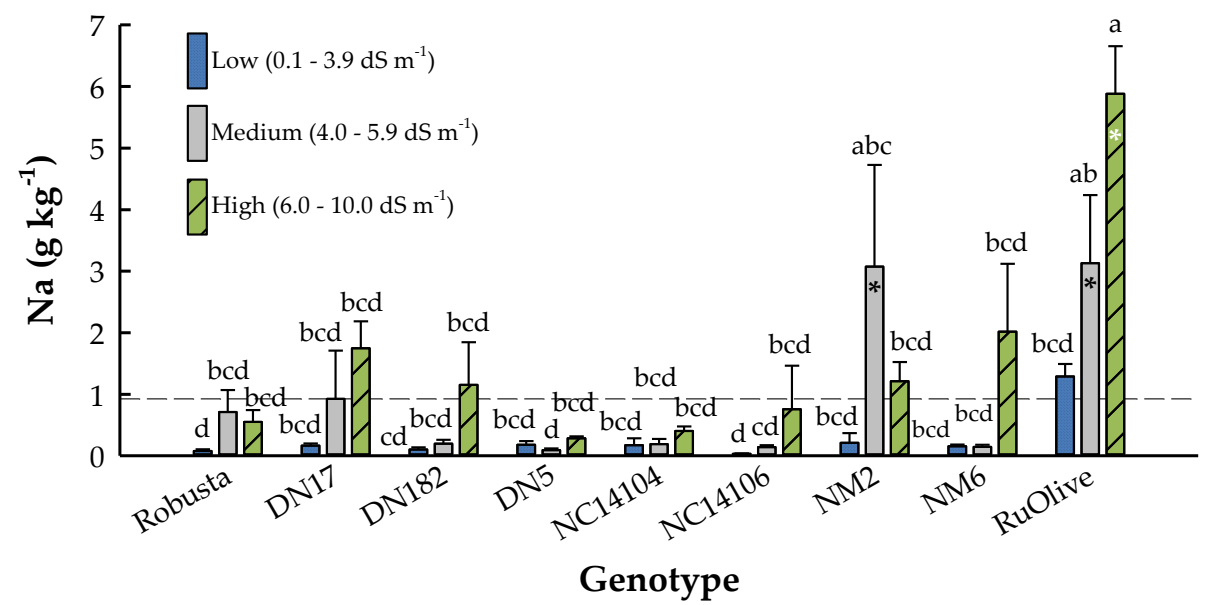

Figure 6. Leaf phytoextraction of sodium $(\mathrm{Na})$ ( \pm standard error) of eight hybrid poplar clones and Russian olive (Elaeagnus angustifolia L.) grown on soils varying in salinity in North Dakota, USA. Soil treatments included low $\left(0.1\right.$ to $\left.3.9 \mathrm{dS} \mathrm{m}^{-1}\right)$, medium $\left(4.0\right.$ to $\left.5.9 \mathrm{dS} \mathrm{m}^{-1}\right)$, and high $\left(6.0\right.$ to $\left.10.0 \mathrm{dS} \mathrm{m}^{-1}\right)$ initial salinity ranges. The dashed line represents the overall mean, while bars with asterisks indicate means that differ from the overall mean at $p<0.05$. Bars with different letters were different according to Fisher's protected LSD at $p<0.05$.

The three most plausible silvicultural causes of the lower-than-expected survival rates in the current study included high soil salinities, extremes of soil moisture availability, and tree shelter effects. First, and the most obvious, is that hybrid poplars are not typically planted in soils with salinity levels in excess of $5 \mathrm{dS} \mathrm{m}^{-1}$ [37]. Although high-biomass clones have been identified that have tolerated such salinity thresholds $[17,20]$, some genotypes in the current study were not adapted to these local site conditions (i.e., P. deltoides $\times$ P. maximowiczii 'NC14104', 'NC14106'). Nevertheless, using methods such as phyto-recurrent selection is warranted for future efforts, wherein genotypes adapted to such soil conditions could be selected before field deployment, thereby increasing the probability of long-term survival and growth $[13,18,19]$. Second, trees in the current study were not irrigated, and they underwent periods of excessive moisture and prolonged drought, both of which likely stressed the trees and limited their response potential to the high-salinity soils [38,39]. While most industrial plantations of hybrid poplars in the Midwest are not irrigated [40], very few have experienced these combinations of concurrent water and salinity stress. Third, hybrid poplars are not typically planted in tree shelters, which in the current study resulted in altered aboveground morphology (i.e., tall and thin trees with reduced branch/leaf development) [41] that likely contributed to confounding of the trees' stress responses from the moisture and salinity mentioned above. While tree shelters protect the trees from deer, they abrade the tree boles and branches where they emerge from the shelter, resulting in deformity. In addition, shelters may affect the trees' ability to harden off, thus leading to winter dieback. Both of which occurred in the current study.

These silvicultural stress responses associated with adaptability, water use mechanisms, and external impacts for survival likely contributed to the observed variability in height, as well. Overall, the inverse relationship between growth and salinity (i.e., growth declined with increasing salinity levels) corroborated those of previous studies [18,22,24]. The magnitude of growth responses of the trees in the current study was similar yet slightly higher than that reported for other hybrid poplars used for salinity-related phytotechnologies. For example, Zalesny and Bauer [42] irrigated three $P$. 
deltoides $\times$ P. nigra clones ('DN34', 'DN17', 'DN182') and two P. nigra $\times$ P. maximowiczii genotypes ('NM2', 'NM6') with low-salinity landfill leachate for one growing season and reported mean height across clones of $99.74 \mathrm{~cm}$, which was $63 \%$ of that reported here for the low initial soil salinity treatment (i.e., 0.1 to $3.9 \mathrm{ds} \mathrm{m}^{-1}$ ). Similarly, six hybrid poplar genotypes ('DN34', 'DN5', 'NC14104', 'NM2', 'NM6', P. deltoides $\times$ P. nigra 'I4551') were irrigated every other day with high salinity (i.e., $8.7 \mathrm{ds} \mathrm{m}^{-1}$ ) landfill leachate from 42 to 70 days after planting, and trees receiving leachate had 15\% greater height than those irrigated with non-saline well water [43]. Four clones ('DN5', 'NC14104', 'NM2', 'NM6') were used in both studies, and their associated height was consistently higher in the current study: 'DN5' (+66\%), 'NC14104' (+65), 'NM2' (+63\%), and 'NM6' (+60\%). After two years, Zalesny et al. [14] reported that eight hybrid poplar genotypes irrigated with high-salinity landfill leachate (i.e., 6.2 to $9.4 \mathrm{dS} \mathrm{m}^{-1}$ ) were 0.98 to $1.81 \mathrm{~m}$ tall compared with 1.44 to $2.13 \mathrm{~m}$ in the current study, resulting in their mean height being 20\% less than that of the current study. Five clones ('DN5', 'NC14104', 'NC14016', 'NM2', 'NM6') were used in both studies, and height comparisons varied among these genotypes. Trees were taller in the current study for 'DN5' (+31\%), 'NC14106' (+26), and 'NM6' (+22\%) yet shorter for 'NC14104' (-7\%) and 'NM2' (-14\%). While not grown in the field, Steppuhn et al. [25] tested first-year stem length of four P. deltoides $\times$ P. nigra clones ('Assiniboine', 'CanAm', 'Manitou', 'Walker') grown in high-salinity solutions ranging in electrical conductivity from 2 to $31 \mathrm{dS} \mathrm{m}^{-1}$, which translated to equivalent electrical conductivity $\left(\mathrm{EC}_{\mathrm{e}}\right)$ of saturated soil paste extracts of 1.0 to $15.5 \mathrm{dS} \mathrm{m}^{-1}$ (i.e., this lower range should be used in comparisons with the current study) [44]. At $\mathrm{EC}_{\mathrm{e}}$ of $6.9 \mathrm{dS} \mathrm{m}^{-1}$, they reported that 'Assiniboine' exhibited $14 \%$ greater stem length than the other three clones, resulting in an $8.4 \%$ stem length reduction per $\mathrm{EC}_{\mathrm{e}}$ unit in their study [25]. Similar clonal trends were observed for their salinity treatments of $2.3 \mathrm{dS} \mathrm{m}^{-1}$ and $4.2 \mathrm{dS} \mathrm{m}^{-1}$ [25], which were equivalent to the low and medium levels of the current study, respectively.

Leaf phytoextraction in the current study was element- and genotype-specific. Russian olive is known to be highly salt tolerant [3], and it is one of few options for establishing trees on the highly saline soils of North Dakota [5,6]. As such, Russian olive exhibited greater $\mathrm{Na}, \mathrm{Cd}$, and Fe leaf concentrations than any of the hybrid poplar genotypes. However, despite expectations, Russian olive also had the worst uptake of $\mathrm{Ca}$ and $\mathrm{Mg}$ of all genotypes tested. Soil concentrations of these elements were analyzed at the time of leaf sampling (Table 2), and conducting a mass balance assessment of the ultimate fate of these metals was beyond the scope of this study. Nevertheless, such experimentation would be a meaningful next step for future projects. While minimal information is available about the phytoextraction potential of Russian olive, leaf uptake of Cd in the current study was $99 \%$ higher than that for a study testing the concentration of heavy metals in leaves of Russian olive trees growing on industrial brownfields [45]. In contrast, leaf phytoextraction of Fe was $43 \%$ lower in the current study, thus corroborating the need to match genotypes with elements of interest and specific soil conditions. Arık and Yaldız [45] also reported Russian olive leaf concentrations of Al, Mn, and $\mathrm{Zn}$ that were 52\%, $48 \%$, and $78 \%$ lower than in the current trees, respectively. Similar results were shown for Cd in a study testing Russian olive as a bioindicator of heavy metal pollution [46], wherein Russian olive trees had $72 \%$ less $\mathrm{Cd}$ concentrations than in the current study. In contrast to comparisons with Arik and Yaldiz [45], Zn concentrations of the current study were 28\% lower (rather than $78 \%$ higher) than those of Aksoy and Şahin [46].

Trees of the current study exhibited moderate levels of salt toxicity symptoms consisting of premature leaf abscission, burned leaf margins, and winter dieback [18]. Leaf phytoextraction of hybrid poplar showed similar salinity stress response trends as for survival and growth. In particular, with the exception of 'DN182' and 'DN17' having much higher concentrations of Mn and Zn than most other clones, respectively, the hybrid poplar genomic groups had two general responses. First, P. nigra $\times P$. maximowiczii genotypes exhibited superior phytoextraction of all elements. Second, $P$. deltoides $\times P$. nigra and $P$. deltoides $\times P$. maximowiczii clones each had leaf concentrations that were similar to both of the other genomic groups, with two exceptions. The P. deltoides $\times P$. nigra clones had $78 \%$ less $\mathrm{Al}$ and $37 \%$ less Ca uptake than the other genomic groups, while the P. deltoides $\times$ P. maximowiczii genotypes 
extracted 53\% less Mn and 155\% less Na relative to the other groups. Furthermore, Bañuelos et al. [20] reported similar variability among seven hybrid poplar genomic groups for leaf concentrations of $\mathrm{Cl}^{-}$and boron (B) following high-salinity irrigation, while Bañuelos et al. [18] and Shannon et al. [19] showed a range in selenium (Se) and B uptake among eight clones belonging to three genomic groups that were irrigated similarly. Although uptake of $\mathrm{Cl}^{-}, \mathrm{B}$, and Se were not tested in the current study, phytoextraction potential of other parameters corroborated previous results for hybrid poplar [47,48]. For example, Chen et al. [24] tested the effect of $\mathrm{NaCl}$ on growth and physiological parameters of $P$. euphratica Oliv. and P. tomentosa Carrière, and they reported that $40 \%$ and $36 \%$ of total Na from their treatments was taken up and distributed to the leaves, respectively. Their substantially less Na uptake into hybrid poplar leaves relative to Russian olive was likely due to known physiological responses of hybrid poplar to Na stress [24]. Specifically, hybrid poplars typically restrict Na transport from roots to leaves [19,23], which has been shown in field trials in the North Central, USA [15]. Testing five of the same genotypes as the current study, Zalesny et al. [15] irrigated the trees with high-salinity landfill leachate for two growing seasons and reported $\mathrm{Na}$ phytoextraction values that were $5 \%$ lower for 'NM6' yet 42\% ('NM2') to 79\% ('DN5') greater than the current study for the other clones. Comparisons between current results and those from the same genotypes irrigated with high-salinity landfill leachate have shown similar outcomes to those reported above. In particular, phytoextraction values were typically higher for leachate-irrigated trees versus those grown on the soils of the current study, yet responses of individual genotypes to specific soil conditions governed phytoextraction potential $[49,50]$. This was especially important in the current study given that soil salinity levels decreased over time. Although it was not directly tested, higher mortality rates in subsequent growing seasons suggested that the trees are extracting and accumulating salts up to and beyond their biological thresholds, thus resulting in impacts to their internal physiological processes. Overall, this is a worthwhile indication that phytoextraction occurred.

\section{Conclusions}

The primary objective in the current study was to test whether any of the hybrid poplar genotypes performed as well or better than Russian olive, to offer landowners a tree-planting alternative to Russian olive on their high-salinity soils. While this objective was to find one or more hybrid poplar genotypes to replace Russian olive, it is worth noting that shrubs and grasses may also have potential for establishing vegetation on these high-salinity soils in North Dakota, USA. As a result, it would be beneficial in future studies for researchers and land managers to test a suite of species belonging to these plant functional groups. Nevertheless, in the current study Russian olive did not survive nor grow as well as expected, having lower survival rates and smaller trees than many of the hybrid poplar clones tested. At the end of three years, $86 \%, 71 \%$, and $43 \%$ of the Russian olive trees were alive in the low-, medium-, and high-salinity soils, respectively. Despite the underperformance of Russian olive, hybrid poplar genomic groups exhibited broad genetic variability, which has led to their use in studies of this nature $[13,18,19]$. The P. deltoides $\times$ P. nigra genomic group had the broadest clonal variability among all traits, with 'Robusta' and 'DN182' exhibiting great potential for the establishment on high-salinity soils, based on survival, growth, and leaf phytoextraction. An interesting observation (as noted in the Materials and Methods) is that 'Robusta' and 'DN17' are the same genotype that came from different nursery sources in the current study (i.e., hence their different nomenclature). Based on statistical contrasts (data not reported), 'Robusta' and 'DN17' did not differ for height within nor across salinity treatments. The same was true for leaf phytoextraction, with two exceptions. First, across treatments, 'Robusta' had 37\% more Al uptake than 'DN17'. Second, across treatments, 'DN17' had 49\% more Zn uptake than 'Robusta'. These results are difficult to interpret, and we ascertain that the differences were due to individual responses to microsites or quality of the planting stock. Nevertheless, as expected, these clones exhibited similar responses overall. In contrast to the P. deltoides $\times$ P. nigra clones, the $P$. deltoides $\times P$. maximowiczii genomic group was not suitable for the soil conditions nor silvicultural applications (e.g., the tree shelters) of the current study. Based on previous results [13,14], 
these clones have been highly successful for phytotechnologies, and their response in the current study supports the need for phyto-recurrent selection to monitor and choose genotypes under controlled conditions before advancing them to the field. Lastly, the P. nigra $\times$ P. maximowiczii clones exhibited the most stable performance across all years and salinity treatments, when considering all the traits simultaneously. Both 'NM2' and 'NM6' had the greatest fourth-year survival and height, as well as average or above average phytoextraction of all elements tested. Overall, our results suggest that $P$. deltoides $\times P$. nigra and $P$. nigra $\times P$. maximowiczii clones that are advanced from phyto-recurrent selection (or a similar selection method), grown in the open air without the use of tree shelters, and monitored for moisture demands (and irrigated during establishment, if necessary) to eliminate the potential for drought-induced stresses are best suited for similar systems of this nature, especially in North Dakota, USA.

Author Contributions: C.M.S. and R.S.Z. conceived and designed the study; C.M.S. established and maintained the field trial; C.M.S., R.S.Z., and B.A.B. conducted measurements; C.M.S. and B.A.B. performed sample laboratory analyses; R.S.Z. and B.A.B. performed the data analyses and interpreted the results; R.S.Z., C.M.S., and B.A.B. wrote the paper.

Funding: This research received no external funding.

Acknowledgments: We are grateful to Elizabeth Rogers and Joe Zeleznik for reviewing earlier versions of this manuscript.

Conflicts of Interest: We used the products mentioned in this manuscript because they met our research needs. Use of specific equipment is left to the discretion of the researcher. Endorsement is not intended by the USDA Forest Service nor USDA Natural Resources Conservation Service.

\section{References}

1. Schultz, R.C.; Colletti, J.P.; Faltonson, R.R. Agroforestry opportunities for the United States of America. Agrofor. Syst. 1995, 31, 117-132. [CrossRef]

2. Franzen, D. Managing saline soils in North Dakota. North Dak. State Univ. Ext. Bull. 2013, SF1087, 11.

3. Monk, R.W.; Wiebe, H.H. Salt tolerance and protoplasmic salt hardiness of various woody and herbaceous ornamental plants. Plant Physiol. 1961, 36, 478-482. [CrossRef] [PubMed]

4. Khamzina, A.; Lamers, J.P.; Vlek, P.L. Nitrogen fixation by Elaeagnus angustifolia in the reclamation of degraded croplands of Central Asia. Tree Physiol. 2009, 29, 799-808. [CrossRef] [PubMed]

5. Enescu, C.M. Russian olive (Elaeagnus angustifolia L.): A multipurpose species with an important role in land reclamation. Curr. Trends Nat. Sci. 2018, 7, 54-60. Available online: http://www.natsci.upit.ro/media/1642/ paper-8.pdf (accessed on 5 April 2019).

6. Katz, G.L.; Shafroth, P.B. Biology, ecology and management of Elaeagnus angustifolia L. (Russian olive) in western North America. Wetlands 2003, 23, 763-777. [CrossRef]

7. Riemenschneider, D.E.; Berguson, W.E.; Dickmann, D.I.; Hall, R.B.; Isebrands, J.G.; Mohn, C.A.; Stanosz, G.R.; Tuskan, G.A. Poplar breeding and testing strategies in the north-central U.S.: Demonstration of potential yield and consideration of future research needs. For. Chron. 2001, 77, 245-253. [CrossRef]

8. Zalesny, R.S., Jr.; Hall, R.B.; Zalesny, J.A.; Berguson, W.E.; McMahon, B.G.; Stanosz, G.R. Biomass and genotype $\times$ environment interactions of Populus energy crops in the Midwestern United States. BioEnergy Res. 2009, 2, 106-122. [CrossRef]

9. Nelson, N.D.; Berguson, W.E.; McMahon, B.G.; Cai, M.; Buchman, D.J. Growth performance and stability of hybrid poplar clones in simultaneous tests on six sites. Biomass Bioenergy 2018, 118, 115-125. [CrossRef]

10. Zalesny, R.S., Jr.; Stanturf, J.A.; Gardiner, E.S.; Perdue, J.H.; Young, T.M.; Coyle, D.R.; Headlee, W.L.; Bañuelos, G.S.; Hass, A. Ecosystem services of woody crop production systems. BioEnergy Res. 2016, 9, 465-491. [CrossRef]

11. Zalesny, R.S., Jr.; Stanturf, J.A.; Gardiner, E.S.; Bañuelos, G.S.; Hallett, R.A.; Hass, A.; Stange, C.M.; Perdue, J.H.; Young, T.M.; Coyle, D.R.; et al. Environmental technologies of woody crop production systems. BioEnergy Res. 2016, 9, 492-506. [CrossRef]

12. Zalesny, R.S., Jr.; Bauer, E.O. Selecting and utilizing Populus and Salix for landfill covers: Implications for leachate irrigation. Int. J. Phytoremed. 2007, 9, 497-511. [CrossRef] [PubMed] 
13. Zalesny, J.A.; Zalesny, R.S., Jr.; Wiese, A.H.; Hall, R.B. Choosing tree genotypes for Phytoremedion of landfill leachate using phyto-recurrent selection. Int. J. Phytoremed. 2007, 9, 513-530. [CrossRef] [PubMed]

14. Zalesny, J.A.; Zalesny, R.S., Jr.; Coyle, D.R.; Hall, R.B. Growth and biomass of Populus irrigated with landfill leachate. For. Ecol. Manag. 2007, 248, 143-152. [CrossRef]

15. Zalesny, J.A.; Zalesny, R.S., Jr.; Wiese, A.H.; Sexton, B.; Hall, R.B. Sodium and chloride accumulation in leaf, woody, and root tissue of Populus after irrigation with landfill leachate. Environ. Pollut. 2008, 155, 72-80. [CrossRef] [PubMed]

16. Zalesny, J.A.; Zalesny, R.S., Jr. Chloride and sodium uptake potential over an entire rotation of Populus irrigated with landfill leachate. Int. J. Phytoremed. 2009, 11, 496-508. [CrossRef] [PubMed]

17. Bañuelos, G.S.; Dhillon, K.S. Developing a sustainable phytomanagement strategy for excessive selenium in western United States and India. Int. J. Phytoremed. 2011, 13, 208-228. [CrossRef] [PubMed]

18. Bañuelos, G.S.; Shannon, M.C.; Ajwa, H.; Draper, J.H.; Jordahl, J.; Licht, L. Phytoextraction and accumulation of boron and selenium by poplar (Populus) hybrid clones. Int. J. Phytoremed. 1999, 1, 81-96. [CrossRef]

19. Shannon, M.C.; Banuelos, G.S.; Draper, J.H.; Ajwa, H.; Jordahl, J.; Licht, L. Tolerance of hybrid poplar (Populus) trees irrigated with varied levels of salt, selenium and boron. Int. J. Phytoremed. 1999, 1, $273-288$. [CrossRef]

20. Bañuelos, G.S.; LeDuc, D.; Johnson, J. Evaluating the tolerance of young hybrid poplar trees to recycled waters high in salinity and boron. Int. J. Phytoremed. 2010, 12, 419-439. [CrossRef]

21. Mirck, J.; Zalesny, R.S., Jr. Mini-review of knowledge gaps in salt tolerance of plants applied to willows and poplars. Int. J. Phytoremed. 2015, 17, 640-650. [CrossRef] [PubMed]

22. Fung, L.E.; Wang, S.S.; Altman, A.; Hütterman, A. Effect of $\mathrm{NaCl}$ on growth, photosynthesis, ion and water relations of four poplar genotypes. For. Ecol. Manag. 1998, 107, 135-146. [CrossRef]

23. Chen, S.; Li, J.; Fritz, E.; Wang, S.; Hüttermann, A. Sodium and chloride distribution in roots and transport in three poplar genotypes under increasing $\mathrm{NaCl}$ stress. For. Ecol. Manag. 2002, 168, 217-230. [CrossRef]

24. Chen, S.; Li, J.; Wang, S.; Fritz, E.; Hüttermann, A.; Altman, A. Effects of $\mathrm{NaCl}$ on shoot growth, transpiration, ion compartmentation, and transport in regenerated plants of Populus euphratica and Populus tomentosa. Can. J. For. Res. 2003, 33, 967-975. [CrossRef]

25. Steppuhn, H.; Kort, J.; Wall, K.G. First year growth response of selected hybrid poplar cuttings to root zone salinity. Can. J. Plant Sci. 2008, 88, 473-483. [CrossRef]

26. Steppuhn, H.; Genuchten, M.T.; Grieve, C.M. Root zone salinity. Crop Sci. 2005, 45, 221-232. [CrossRef]

27. Smesrud, J.K.; Duvendack, G.D.; Obereiner, J.M.; Jordahl, J.L.; Madison, M.F. Practical salinity management for leachate irrigation to poplar trees. Int. J. Phytoremed. 2012, 14, 26-46. [CrossRef] [PubMed]

28. Rockwood, D.L.; Naidu, C.V.; Carter, D.R.; Rahmani, M.; Spriggs, T.A.; Lin, C.; Alker, G.R.; Isebrands, J.G.; Segrest, S.A. Short-rotation woody crops and Phytoremedion: Opportunities for agroforestry? Agrofor. Syst. 2004, 61, 51-63. [CrossRef]

29. Limmer, M.A.; Wilson, J.; Westenberg, D.; Lee, A.; Siegman, M.; Burken, J.G. Phytoremedion removal rates of benzene, toluene, and chlorobenzene. Int. J. Phytoremed. 2018, 20, 666-674. [CrossRef]

30. Larson, P.R.; Isebrands, J.G. The plastochron index as applied to developmental studies of cottonwood. Can. J. For. Res. 1971, 1, 1-11. [CrossRef]

31. Headlee, W.L.; Zalesny, R.S., Jr.; Donner, D.M.; Hall, R.B. Using a process-based model (3-PG) to predict and map hybrid poplar biomass productivity in Minnesota and Wisconsin, USA. BioEnergy Res. 2013, 6, 196-210. [CrossRef]

32. Lazarus, W.; Headlee, W.L.; Zalesny, R.S., Jr. Impacts of supplyshed-level differences in productivity and land costs on the economics of hybrid poplar production in Minnesota, USA. BioEnergy Res. 2015, 8, 231-248. [CrossRef]

33. Zalesny, R.S., Jr.; Bauer, E.O.; Hall, R.B.; Zalesny, J.A.; Kunzman, J.; Rog, C.J.; Riemenschneider, D.E. Clonal variation in survival and growth of hybrid poplar and willow in an in situ trial on soils heavily contaminated with petroleum hydrocarbons. Int. J. Phytoremed. 2005, 7, 177-197. [CrossRef] [PubMed]

34. Zalesny, R.S., Jr.; Bauer, E.O. Genotypic variability and stability of poplars and willows grown on nitrate-contaminated soils. Int. J. Phytoremed. 2019. [CrossRef] [PubMed]

35. Zalesny, R.S., Jr.; Headlee, W.L.; Gopalakrishnan, G.; Bauer, E.O.; Hall, R.B.; Hazel, D.W.; Isebrands, J.G.; Licht, L.A.; Negri, M.C.; Guthrie-Nichols, E.; et al. Ecosystem services of poplar at long-term Phytoremedion sites in the Midwest and Southeast, United States. WIREs Energy Environ. 2019, in press. [CrossRef] 
36. Minogue, P.J.; Miwa, M.; Rockwood, D.L.; Mackowiak, C.L. Removal of nitrogen and phosphorus by Eucalyptus and Populus at a tertiary treated municipal wastewater sprayfield. Int. J. Phytoremed. 2012, 14, 1010-1023. [CrossRef] [PubMed]

37. Neuman, D.S.; Wagner, M.; Braatne, J.H.; Howe, J. Part II: Stress physiology-Abiotic. In Biology of Populus and its Implications for Management and Conservation; Stettler, R.F., Bradshaw, H.D., Jr., Heilman, P.E., Hinckley, T.M., Eds.; NRC Research Press, National Research Council of Canada: Ottawa, ON, Canada, 1996; Chapter 17; pp. 423-458. Available online: www.nrcresearchpress.com/doi/book/10.1139/9780660165066\# .XKUA8JAUmRs (accessed on 5 April 2019).

38. Dickmann, D.I.; Liu, Z.; Nguyen, P.V.; Pregitzer, K.S. Photosynthesis, water relations, and growth of two hybrid Populus genotypes during a severe drought. Can. J. For. Res. 1992, 22, 1094-1106. [CrossRef]

39. Liu, Z.; Dickmann, D.I. Responses of two hybrid Populus clones to flooding, drought, and nitrogen availability. I. Morphology and growth. Can. J. Bot. 1992, 70, 2265-2270. [CrossRef]

40. Zalesny, R.S., Jr.; Donner, D.M.; Coyle, D.R.; Headlee, W.L. An approach for siting poplar energy production systems to increase productivity and associated ecosystem services. For. Ecol. Manag. 2012, 284, 45-58. [CrossRef]

41. Zalesny, J.A.; Zalesny, R.S., Jr.; Coyle, D.R.; Hall, R.B.; Bauer, E.O. Clonal variation in morphology of Populus root systems following irrigation with landfill leachate or water during 2 years of establishment. BioEnergy Res. 2009, 2, 134-143. [CrossRef]

42. Zalesny, R.S., Jr.; Bauer, E.O. Evaluation of Populus and Salix continuously irrigated with landfill leachate II. Soils and early tree development. Int. J. Phytoremed. 2007, 9, 307-323. [CrossRef] [PubMed]

43. Zalesny, R.S., Jr.; Wiese, A.H.; Bauer, E.O.; Riemenschneider, D.E. Ex situ growth and biomass of Populus bioenergy crops irrigated and fertilized with landfill leachate. Biomass Bioenergy 2009, 33, 62-69. [CrossRef]

44. Ayers, R.S.; Westcot, D.W. Water Quality for Agriculture; FAO Irrigation and Drainage Paper 29 (Revision 1); Food and Agriculture Organization of the United Nations: Rome, Italy, 1985; p. 174. Available online: http://www.fao.org/3/t0234e/t0234e00.htm (accessed on 5 April 2019).

45. Arık, F.; Yaldız, T. Heavy metal determination and pollution of the soil and plants of southeast Tavşanlı (Kütahya, Turkey). Clean Soil Air Water 2010, 38, 1017-1030. [CrossRef]

46. Aksoy, A.; Şahin, U. Elaeagnus angustifolia L. as a biomonitor of heavy metal pollution. Turk. J. Bot. 1999, 23, $83-87$.

47. Burges, A.; Alkorta, I.; Epelde, L.; Garbisu, C. From Phytoremedion of soil contaminants to phytomanagement of ecosystem services in metal contaminated sites. Int. J. Phytoremed. 2018, 20, 384-397. [CrossRef]

48. Pilipović, A.; Zalesny, R.S., Jr.; Rončević, S.; Nikolić, N.; Orlović, S.; Beljin, J.; Katanić, M. Growth, physiology, and phytoextraction potential of poplar and willow established in soils amended with heavy-metal contaminated, dredged river sediments. J. Environ. Manag. 2019, 239, 352-365. [CrossRef] [PubMed]

49. Zalesny, R.S., Jr.; Bauer, E.O. Evaluation of Populus and Salix continuously irrigated with landfill leachate I. Genotype-specific elemental Phytoremedion. Int. J. Phytoremed. 2007, 9, 281-306. [CrossRef]

50. Zalesny, J.A.; Zalesny, R.S., Jr.; Wiese, A.H.; Sexton, B.T.; Hall, R.B. Uptake of macro- and micro-nutrients into leaf, woody, and root tissue of Populus after irrigation with landfill leachate. J. Sustain. For. 2008, 27, 303-327. [CrossRef]

(C) 2019 by the authors. Licensee MDPI, Basel, Switzerland. This article is an open access article distributed under the terms and conditions of the Creative Commons Attribution (CC BY) license (http://creativecommons.org/licenses/by/4.0/). 